Published in final edited form as:

Biol Chem. 2014 January ; 395(1): 61-81. doi:10.1515/hsz-2013-0220.

\title{
Lipid antigens in immunity
}

\author{
C. Marie Dowds, \\ Department of Internal Medicine I, University Medical Center Schleswig-Holstein, \\ Schittenhelmstraße 12, D-24105 Kiel, Germany \\ Sabin-Christin Kornell, \\ Department of Internal Medicine I, University Medical Center Schleswig-Holstein, \\ Schittenhelmstraße 12, D-24105 Kiel, Germany
}

Richard S. Blumberg, and

Division of Gastroenterology, Hepatology, and Endoscopy, Brigham and Women's Hospital, Harvard Medical School, 75 Francis Street, Boston, MA 02115, USA

\section{Sebastian Zeissig}

Department of Internal Medicine I, University Medical Center Schleswig-Holstein, Schittenhelmstraße 12, D-24105 Kiel, Germany

Richard S. Blumberg: rblumberg@partners.org; Sebastian Zeissig: szeissig@1med.uni-kiel.de

\begin{abstract}
Lipids are not only a central part of human metabolism but also play diverse and critical roles in the immune system. As such, they can act as ligands of lipid-activated nuclear receptors, control inflammatory signaling through bioactive lipids such as prostaglandins, leukotrienes, lipoxins, resolvins, and protectins, and modulate immunity as intracellular phospholipid- or sphingolipidderived signaling mediators. In addition, lipids can serve as antigens and regulate immunity through the activation of lipid-reactive T cells, which is the topic of this review. We will provide an overview of the mechanisms of lipid antigen presentation, the biology of lipid-reactive T cells, and their contribution to immunity.
\end{abstract}

\section{Keywords}

CD1; CD1a; CD1b; CD1c; CD1d; (NK)T

\section{CD1 proteins survey subcellular compartments for lipids}

Lipid antigens are presented by atypical MHC class I proteins of the CD1 family. In contrast to the polymorphic nature of classical MHC class I, CD1 genes exhibit little sequence diversity with few nonsynonymous single-nucleotide polymorphisms (Zimmer et al., 2009; Seshadri et al., 2013). All mammalian species investigated so far express at least one CD1 protein, suggesting conservation of the CD1 system in mammals (Kasmar et al., 2009). In humans, lipid antigens are presented by group $1(\mathrm{CD} 1 \mathrm{a}, \mathrm{CD} 1 \mathrm{~b}$, and CD1c) and group 2 
(CD1d) CD1 isoforms (Porcelli et al., 1989, 1992; Balk et al., 1991; Blumberg et al., 1991; Beckman et al., 1994; Kawano et al., 1997). Mice lack expression of group 1 CD1 and contain two highly homologous CD1d-encoding genes ( $C d l d l$ and $C d l d 2$ ), whereby the Cdld2 gene contains a frameshift in the C57BL/6 strain that prevents cell surface expression of the encoded protein (Park et al., 1998).

$\mathrm{T}$ cells responding to lipid antigens are CD1a-, CD1b-, CD1c-, or CD1d-restricted and, in the case of CD1d, have been termed natural killer T (NKT) cells. Based on their T cell receptor (TCR) repertoire, NKT cells are further distinguished into invariant NKT (iNKT) cells expressing a semi-invariant TCR and non-invariant NKT cells with a more diverse TCR repertoire (see further below).

CD1 family members are considered atypical MHC class I proteins and share selected structural and functional characteristics of classical MHC class I and class II proteins. Thus, similar to MHC class I, CD1 proteins contain three extracellular domains $\left(a_{1}, a_{2}\right.$, and $\left.a_{3}\right)$, a transmembrane domain, and a C-terminal intracellular domain and are synthesized in the endoplasmic reticulum (ER) in a manner dependent on the ER chaperones calreticulin and calnexin as well as the thiol oxireductase ERp57 (Kang and Cresswell, 2002; Cohen et al., 2009). However, differences in the biosynthesis of CD1 and MHC class I exist with regard to the sequence of these interactions and their physiological implications (Kang and Cresswell, 2002). Thus, in contrast to MHC class I, calreticulin, calnexin, and ERp57 interact with the CD1d heavy chain before associating with $\beta_{2}$-microglobulin $\left(\beta_{2} \mathrm{~m}\right)$ (Kang and Cresswell, 2002). As a consequence, the binding of $\beta_{2} \mathrm{~m}$ is less critical for folding of CD1d compared with MHC class I, which may explain the occurrence of functionally competent $\beta_{2}$ m-independent CD1d (Balk et al., 1994; Koh et al., 2008). CD1 isoformspecific differences also exist in that ER exit of CD1b but not CD1d is $\beta_{2} \mathrm{~m}$-dependent (Balk et al., 1994; Sugita et al., 1997).

In the ER, CD1 loads cellular lipids common in this compartment such as glycerophospholipids (GPLs), including phosphatidylcholine (PC) and phosphatidylinositol (PI) (Park et al., 2004; Yuan et al., 2009). Although these findings were obtained with ERretained forms of $\mathrm{CD} 1 \mathrm{~d}$, the association of $\mathrm{PC}$ with secreted forms of $\mathrm{CD} 1 \mathrm{~b}$ and $\mathrm{CD} 1 \mathrm{c}$ suggests that similar mechanisms likely apply to group 1 CD1 (Garcia-Alles et al., 2006; Haig et al., 2011). Loading of lipids onto CD1d in the ER is facilitated by lipid transfer molecules expressed in this compartment such as microsomal triglyceride transfer protein (MTP) and may contribute to ligand-induced stabilization of CD1 during biosynthesis (Brozovic et al., 2004; Dougan et al., 2005, 2007; Kaser et al., 2008; Odyniec et al., 2010; Zeissig et al., 2010). This concept is supported by the observation that mutations in the gene encoding for MTP (MTTP), as found in human abetalipoproteinemia (ABL), are associated with proteasomal degradation of CD1a, CD1b, and CD1c (Zeissig et al., 2010).

Following biosynthesis in the ER, CD1 traffics through the secretory pathway to the plasma membrane, where acquired lipids are presented to lipid-reactive T cells. Interestingly, the repertoire of lipids associated with engineered, ER-retained CD1d (ER-CD1d) differs from that observed with soluble CD1d (sCD1d), which lacks the transmembrane domain and is released at the cell surface following completion of trafficking through the secretory 
pathway. Thus, GPLs were found to be the dominant group of lipids associated with ERCD1d, whereas both sphingolipids and GPLs were bound to sCD1d (Cox et al., 2009; Yuan et al., 2009; Muindi et al., 2010). This indicates that either unloaded CD1 proteins proceed to the Golgi complex, where they bind sphingolipids generated in this compartment or, more likely, that lipids loaded in the ER are replaced in the Golgi either spontaneously or facilitated by lipid transfer and editing proteins yet to be identified.

In addition to pathways shared with MHC class I, CD1 trafficking patterns partially overlap with those of MHC class II. Thus, CD1 is internalized after reaching the plasma membrane and traffics through the endolysosomal pathway in a manner dependent on the CD1 isoform. $\mathrm{CD} 1 \mathrm{a}, \mathrm{CD} 1 \mathrm{c}$, and human CD1d are recruited to early endosomes and the endocytic recycling compartment, whereas $\mathrm{CD} 1 \mathrm{~b}$ and $\mathrm{mCD} 1 \mathrm{~d}$ show additional trafficking into lysosomes (Cohen et al., 2009). CD1 isoform-specific trafficking is thereby determined by interactions of the cytoplasmic tail of CD1 with adaptor protein (AP) 2 and 3 leading to internalization through interaction with AP-2 (all CD1 isoforms except for CD1a) and subsequent lysosomal recruitment through interaction with AP-3 (CD1b and mCD1d) (Sugita et al., 1996, 1999, 2000; Chiu et al., 1999; Briken et al., 2000; Jayawardena-Wolf et al., 2001; Chiu et al., 2002). As a consequence of differences in trafficking patterns, CD1 isoforms survey different endolysosomal compartments, where cellular GPLs and sphingolipids loaded in the secretory pathway are exchanged against other endogenous (self) or exogenous (microbial, nutritional) lipids presented to CD1-restricted T cells after recycling of $\mathrm{CD} 1$ to the cell surface.

Endolysosomal lipid exchange is facilitated by low $\mathrm{pH}$, lipid transfer and editing proteins, and enzymes involved in lipid processing and catabolism. Acidification within the endolysosomal system ensures optimal activity of hydrolytic enzymes, stabilizes CD1 in the absence of bound lipid (Odyniec et al., 2010), and facilitates lipid loading through direct effects on the conformation of CD1 (Ernst et al., 1998; Relloso et al., 2008). In addition, lipid transfer and editing proteins such as saposin family members and GM2 activator contribute to CD1 lipid loading in the endolysosomal system through extraction of lipids from membranes and transfer onto CD1 as well as potentially through prevention of an irreversible collapse of the CD1 binding cavity in the lipid-free intermediate state (Kang and Cresswell, 2004; Winau et al., 2004; Zhou et al., 2004a,b; Yuan et al., 2007; Garzon et al., 2013). In addition, cathepsin L expression in thymocytes is required for the activation and positive selection of iNKT cells and may act through the assistance in the conversion of prosaposin into saposins (Honey et al., 2002). Further, endolysosomal enzymes involved in the processing of glycolipid headgroups as well as the lipid tails play major roles in the generation of antigenic CD1 lipids. Thus, glycosidases including $\alpha$ - and $\beta$-galactosidase, $\alpha$ mannosidase, and $\beta$-hexosaminidase are involved in the trimming of the headgroups of complex glycosphingolipids (GSLs) and bacterial glycosylphosphoinositides, which facilitates lipid headgroup recognition by the NKT-TCR (Sieling et al., 1995; Prigozy et al., 2001; Zhou et al., 2004a,b; de la Salle et al., 2005; Gadola et al., 2006). Deficiency in lysosomal glycolipid-processing enzymes is associated with storage disorders in humans and mice (Kolter and Sandhoff, 2010) and affects lipid antigen presentation through direct effects on the processing of CD1-restricted lipid antigens and indirect effects through interference with lysosomal function (Sieling et al., 1995; Prigozy et al., 2001; Zhou et al., 
2004a,b; de la Salle et al., 2005; Gadola et al., 2006). In addition to glycosidases, CD1e, the sole known group $3 \mathrm{CD} 1$ member, facilitates a-mannosidase-dependent processing of glycolipids and directly transfers diacylated phosphatidylinositol mannoside onto CD1b (de la Salle et al., 2005; Facciotti et al., 2011; Garcia-Alles et al., 2011; Cala-De Paepe et al., 2012). Finally, the processing of lipid tails, for example, by phospholipase $A_{2}\left(P_{2} A_{2}\right)$ enzymes, occurs in various subcellular compartments including the endolysosomal system and modulates the antigenicity of CD1 lipids (Fox et al., 2009; Zeissig et al., 2012; Paduraru et al., 2013).

Together, broad and isoform-dependent trafficking of CD1 as well as the concerted action of lipid transfer and processing enzymes facilitate a survey of subcellular compartments for CD1 binding self-lipids and foreign lipids.

\section{CD1 binds a broad spectrum of self-lipids}

$\mathrm{CD} 1$ isoforms have two or four hydrophobic pockets $\left(\mathrm{A}^{\prime}, \mathrm{C}^{\prime}, \mathrm{F}^{\prime}\right.$, and $\left.\mathrm{T}^{\prime}\right)$, which accommodate the hydrophobic tail of lipid ligands, whereas the lipid headgroup is presented to the NKT-TCR (Moody et al., 2005; De Libero et al., 2009; Girardi and Zajonc, 2012; Rossjohn et al., 2012). Volumes of the binding grooves vary significantly between CD1 isoforms with CD1a at the lower end $\left(1200 \AA^{3}\right)$ and CD1b at the upper end of the spectrum $\left(2400 \AA^{3}\right.$ ) (Moody et al., 2005; Cohen et al., 2009; De Libero et al., 2009). Consequently, CD1b has been shown to capture exogenous lipids with combined alkyl chain lengths of 7086 carbons, whereas the total lipid tail bound by other CD1 isoforms is in the range of 36-46 carbons (Moody et al., 2005; Cohen et al., 2009). Lipids with up to four alkyl chains were found to be associated with CD1.

In accordance with few restrictions for CD1 binding, a large spectrum of self- and foreign lipids associates with CD1. Lipidomics studies of endogenous lipids associated with individual CD1 members revealed several hundred lipids with distinct mass-to-charge ratios bound to each CD1 isoform in a single cell line in vitro (Cox et al., 2009; Huang et al., 2011). Of those, 5-25\% of lipids were CD1 isoform-specific (Huang et al., 2011).

With regard to CD1d, the most extensively studied CD1 member, the spectrum of associated lipids reflected that of the total cellular or compartmental abundance of lipids. Thus, GPLs and sphingolipids were found to be the major groups of lipids associated with CD1d (Cox et al., 2009; Yuan et al., 2009; Muindi et al., 2010; Haig et al., 2011). Within GPLs, abundant cellular lipids such as PC and phosphatidylethanolamine (PE) as well as less abundant lipids such as phosphatidylserine, PI, phosphatidylglycerol, and phosphatidic acid were bound to CD1d (Park et al., 2004; Cox et al., 2009; Shiratsuchi et al., 2009; Yuan et al., 2009; Haig et al., 2011). Among sphingolipids, both sphingomyelin and GSLs were found to be associated with CD1d (Cox et al., 2009; Yuan et al., 2009; Muindi et al., 2010; Haig et al., 2011). A detailed characterization of cellular and CD1dbound GSLs revealed that the relative abundance of GSLs associated with CD1d did not solely reflect their cellular abundance (Muindi et al., 2010). This suggests that the subcellular localization of CD1d and potential lipid ligands as well as the abundance and activity of lipid processing and transfer proteins may contribute to the repertoire of CD1d-associated lipids. In accordance with the concept 
of compartmental effects on the CD1d lipidome, the spectrum of GPLs and sphingolipids associated with CD1d differed between CD1d molecules engineered to selectively traffic through the secretory pathway compared with those that exhibited additional endolysosomal trafficking (Yuan et al., 2009; Muindi et al., 2010). Thus, lysophospholipids were predominantly associated with CD1d proteins, which maintain the ability to undergo endolysosomal trafficking, whereas the ganglioside GM2 was only detected in CD1d engineered to selectively survey secretory compartments (Yuan et al., 2009; Muindi et al., 2010).

Similar studies on endogenous ligands have recently been performed for secreted forms of group $1 \mathrm{CD} 1$, which selectively traffic through the secretory but not the endolysosomal pathway due to lack of the CD1 transmembrane domain and the intracellular C-terminus (Haig et al., 2011; Huang et al., 2011). These studies revealed a large overlap in the spectrum of lipids associated with group 1 and group 2 CD1 with some noteworthy isoformspecific distinctions. Thus, CD1b, despite having a significantly larger lipid binding groove than other CD1 isoforms, captures low-mass lipids such as diacylglycerols and deoxyceramides (Facciotti et al., 2011; Huang et al., 2011). These lipids act as scaffolds and facilitate subsequent parallel binding of lipids that would otherwise not fully occupy the CD1b-binding groove, thus contributing to optimal positioning of these lipids for T-cell recognition (Garcia-Alles et al., 2006; Facciotti et al., 2011; Huang et al., 2011). In addition, these and other lipids may act as spaceholders for subsequent exchange against lipids with long acyl chains, which fully occupy the CD1b groove (Huang et al., 2011).

\section{Antigenicity is limited to a small subset of self-lipids}

Group $1 \mathrm{CD} 1$ expression is limited to professional antigen-presenting cells (APCs) including, in case of CD1c, a subset of B cells (Cohen et al., 2009). In contrast, CD1d is broadly expressed by professional and non-professional APCs including epithelial and endothelial cells (Blumberg et al., 1991; Geissmann et al., 2005; Cohen et al., 2009). As CD1d binds to a wide variety of self-lipids, it may provide a constant source of antigens for CD1d-restricted NKT cells, both in the thymus and the periphery. In accordance with this concept, autoreactivity, i.e., CD1-dependent activation by APCs in the absence of exogenous antigen, is a hallmark of NKT cells. However, the search for self-lipid antigens involved in NKT cell activation revealed that the majority of CD1d-binding lipids exhibit little or no antigenicity (Fox et al., 2009; Brennan et al., 2011; Pei et al., 2011; Facciotti et al., 2012; Zeissig et al., 2012). Noteworthy examples of antigenic CD1d self-lipids that activate iNKT cells include GSLs such as isoglobotrihexosylceramide (iGb3), $\beta$ glucosylceramide ( $\beta$-GlcCer), $\beta$-galactosylceramide ( $\beta$-GalCer), and lysosphingomyelin as well as phospholipids such as lysophosphatidylcholine (LPC), ether-bonded lysophosphatidylethanolamine (pLPE) and lysophosphatidic acid (eLPA) (Figure 1) (Zhou et al., 2004a,b; Fox et al., 2009; Brennan et al., 2011; Facciotti et al., 2012). In addition, CD1d self-lipids that exhibit antigenicity for non-invariant NKT cells include ester-bonded lysophosphatidylethanolamine (LPE) and the GSLs sulfatide, $\beta$-GlcCer and $\beta$-GalCer, whereby the lyso-derivatives of the GSLs showed increased antigenicity (Figure 1) (Jahng et al., 2004; Roy et al., 2008; Brennan et al., 2011; Rhost et al., 2012; Zeissig et al., 2012). The relative contribution of these antigenic lipids to NKT cell-positive selection in the thymus 
and activation in the periphery as well as the mechanisms underlying species-specific differences in self-antigen-mediated NKT cell activation are currently not clear and require further analysis. Similarly, the mechanisms that prevent autoimmunity in the presence of antigenic self-lipids require further study but may include the balance of antigenic and nonantigenic CD1d lipids.

Mechanistically, the discrepancy between the number of CD1d-binding lipids and those associated with NKT cell antigenicity is the consequence of a rather non-selective binding mode based on hydrophobic interactions between CD1d and the aliphatic lipid tail, whereas antigenicity follows more strict, but only partially understood structural requirements that allow for recognition of the CD1d-lipid complex by the NKT-TCR (De Libero et al., 2009; Girardi and Zajonc, 2012; Rossjohn et al., 2012). These structure-function relationships at the interface of the CD1d-lipid complex and the NKT-TCR have recently been the focus of excellent reviews and will only be briefly outlined here (De Libero et al., 2009; Girardi and Zajonc, 2012; Rossjohn et al., 2012). Thus, recognition of the CD1d-lipid complex by the NKT-TCR is based on interactions between the TCR and CD1d as well as the headgroup of lipids. Thereby, the molecular nature of the headgroup, its size, and its linkage to the lipid backbone affect TCR recognition (De Libero et al., 2009; Girardi and Zajonc, 2012; Rossjohn et al., 2012). Moreover, the length, composition, and saturation of lipid tails modulate positioning of lipids within CD1, thus regulating TCR recognition (De Libero et al., 2009; Girardi and Zajonc, 2012; Rossjohn et al., 2012). Remarkably, the spectrum of antigenic headgroups extends from more (iGb3) or less complex ( $\beta$-GlcCer) carbohydrates and phospholipid headgroups (LPC and LPE) to the minimal sugar-free phosphate anion headgroup of eLPA (Zhou et al., 2004a,b; Brennan et al., 2011; Facciotti et al., 2012; Ly et al., 2013). In case of GSLs, mammalian $\beta$-glycosidic linkage confers lower TCR affinity compared with microbial a-glycosidic linkage because it requires an induced fit of the NKTTCR (Pellicci et al., 2011; Yu et al., 2011). Similarly, complex GSL headgroups may require enzymatic processing and trimming for TCR recognition, whereas some adaptation to bulkier hexose headgroups such as that of iGb3 can also be achieved by an induced TCR fit (Florence et al., 2009). In contrast, the mechanisms that confer specificity to NKT-TCR recognition of some but not other phospholipids and the mechanistic basis of the observed increased potency of lyso-variants of phospholipids and sphingolipids are just beginning to emerge (Lopez-Sagaseta et al., 2012).

Finally, recent technical advances including group $1 \mathrm{CD} 1$ tetramers and lipidome analysis of engineered group $1 \mathrm{CD} 1$ proteins provide the basis for ongoing studies of the CD1a-, CD1b-, and CD1c-associated lipidome and the mechanisms that govern recognition by group 1 CD1 TCRs (Huang et al., 2011; Kasmar et al., 2011; Ly et al., 2013; Van Rhijn et al., 2013). These studies have revealed a significant overlap in the spectrum of lipids associated with group 1 and group 2 CD1 (Huang et al., 2011). Moreover, commonalities in self-lipid recognition by group 1 and 2 CD1-restricted (NK)T cells are likely to exist, given the recognition of particular self-antigens such as sulfatide across group 1 and group 2 CD1restricted (NK)T cells (Shamshiev et al., 2002; Jahng et al., 2004). However, it is conceivable that the spectrum of antigenic lipids associated with group $1 \mathrm{CD} 1$ exceeds that of CD1d given the diversity in the TCR repertoire of group 1 CD1-restricted T cells (Grant et al., 1999). 


\section{Environmental influences shape the CD1 self-lipid repertoire}

Recent studies have revealed that the repertoire of CD1 self-lipids is not static but rather subject to continuous regulation in response to microbial, inflammatory, and likely metabolic stimuli. Such alterations may act in concert with microbiota- and inflammationinduced maturation of APCs, upregulation of CD1 expression, and CD1-dependent and CD1-independent (NK)T cell activation to contribute to CD1- and (NK)T cell-dependent immunity. Moreover, metabolic factors such as serum lipids and lipoproteins are involved in the regulation of CD1 expression and further contribute to the control of CD1-dependent immunity (Gogolak et al., 2007; Leslie et al., 2008).

Microbial infection and exposure to toll-like receptor (TLR) agonists affects cellular lipid metabolism and leads to alterations in the spectrum and antigenicity of CD1 lipids, particularly through the regulation of sphingolipid metabolism (De Libero et al., 2005; Paget et al., 2007; Salio et al., 2007; Muindi et al., 2010; Brennan et al., 2011). Recent studies have provided a comprehensive characterization of microbial-induced alterations in the sphingolipid self-antigen repertoire associated with CD1d and revealed $\beta$-GlcCer as a potent self-antigen for NKT cells, which is induced upon bacterial infection or TLR stimulation (Muindi et al., 2010; Brennan et al., 2011). In addition, it has recently been demonstrated that microbial-induced alterations in the endogenous CD1d lipid repertoire are not limited to bacterial infection. Thus, hepatitis B virus (HBV) infection is, among other broad alterations in the hepatocyte lipid profile, associated with increased abundance of PE. PE binds to $\mathrm{CD} 1 \mathrm{~d}$ but is non-antigenic and requires HBV-dependent induction of selected secretory $\mathrm{PLA}_{2}$ enzymes for hydrolysis into LPE (Figure 1), which is strongly antigenic for a subgroup of non-invariant NKT cells (Zeissig et al., 2012). Noteworthy, alterations in the abundance of several antigenic CD1d lipids, including $\beta$-GlcCer and lysophospholipids, are not restricted to specific microbial infections but represent common signatures of inflammatory and malignant diseases (Fuchs et al., 2012; Santos and Schulze, 2012). It is therefore likely that the CD1 self-lipid repertoire is under continuous metabolic and immune-mediated control, with broad implications for (NK)T cell-dependent immunity at steady state and during inflammatory, malignant, and metabolic disorders.

\section{Microbial organisms contain potent CD1 lipid antigens}

In addition to shaping the repertoire of CD1 self-lipids, environmental and particularly microbial exposure provides a wealth of exogenous lipid antigens, which contributes to antimicrobial responses of lipid-reactive T- and NKT cells in the context of local or systemic infections (Kinjo and Kronenberg, 2009; Brennan et al., 2013).

The structural complexity of microbial-derived CD1 lipid antigens considerably exceeds that of self-lipid antigens. Thus, seminal studies by Brenner, Porcelli, Moody, and others revealed that group $1 \mathrm{CD} 1$ associates with a wide variety of mycobacterial phospholipids, glycolipids, mycolic acids, lipopeptides, mycoketides, and isoprenoids, which act as antigens for group 1 CD1-restricted T cells (Moody et al., 2005; Cohen et al., 2009). Similarly, various group 2 CD1 (CD1d)-binding, NKT cell-activating lipids have been described and include a-linked GSLs derived from Sphingomonas species (e.g., GSL-1; 
Figure 2) (Kinjo et al., 2005; Mattner et al., 2005; Sriram et al., 2005), diacylglycerolcontaining glycolipids derived from Borrelia burgdorferi (e.g., Bb-GLIIc; Figure 2) (Kinjo et al., 2006), Streptococcus pneumoniae and group B Streptococcus (Kinjo et al., 2011), phospholipids derived from mycobacteria and Corynebacterium spp. [e.g., Corynebacterium glutamicum diphosphatidylglycerol (Cg-DPG); Figure 2] (Fischer et al., 2004; Tatituri et al., 2013), a cholesterol ester produced by Helicobacter pylori (PI-57; Figure 2) (Chang et al., 2011), and lipophosphoglycans derived from Leishmania donovani (Amprey et al., 2004), and Entamoeba histolytica (Lotter et al., 2009).

Exogenous antigens typically associate with a particular CD1 isoform and load onto CD1 either at the plasma membrane or in the endolysosomal pathway. The specificity of lipid binding to a particular CD1 isoform relates both to the structural requirements of these interactions and differences in the compartmental distribution of CD1 isoforms and lipids. Thus, CD1a contains a shallow and laterally oriented $\mathrm{F}^{\prime}$ pocket, which, for example, facilitates binding and presentation of the peptide moiety of the lipopeptide didehydroxymycobactin (Moody et al., 2004; Zajonc et al., 2005). In contrast, binding of mycobacteria-associated long-chain mycolic acids to CD1b is facilitated by the large antigen binding groove of $\mathrm{CD} 1 \mathrm{~b}$ and specific trafficking of these lipids to late endosomes, where CD1b is located and where loading is facilitated by acidic pH (Moody et al., 2002; Relloso et al., 2008). In case of mycobacterial mannosyl phosphomycoketide, specific binding to CD1c is conferred by methyl branches found in foreign mycoketides but not mammalian self-lipids (Scharf et al., 2010; Ly et al., 2013). These examples of specific interactions between microbial lipids and CD1 illustrate the unique ability of CD1 to survey different subcellular compartments for exogenous, microbial lipid antigens in a CD1 isoformdependent manner.

In the context of an infection, antigen-dependent and antigen-independent pathways contribute to the activation of lipid-reactive T cells and particularly CD1d-restricted NKT cells (see below). For these reasons, the contribution of an individual microbial-derived CD1 lipid antigen to immune-mediated control of a particular infection is often difficult to assess. However, studies using group 1 and group 2 CD1 tetramers loaded with microbial lipids could demonstrate the presence of (NK)T cells reactive or cross-reactive to these lipids in humans and mice (Fischer et al., 2004; Kinjo et al., 2005; Mattner et al., 2005; Sriram et al., 2005; Kinjo et al., 2006; Kasmar et al., 2011; Ly et al., 2013; Van Rhijn et al., 2013). Moreover, expansion of mycobacterial lipid-reactive group $1 \mathrm{CD} 1$-restricted T cells in humans and mice following $M$. tuberculosis infection suggests that these T cells and the lipid antigens recognized participate in the antimicrobial immune response in vivo (Felio et al., 2009; Van Rhijn et al., 2013). Future studies in animal models will be critical to delineate the contribution of individual lipid antigens to antimicrobial immune responses through genetic and chemical manipulation of metabolic pathways associated with the generation of these lipids.

\section{Lipid-reactive T cells}

Endogenous and exogenous lipids presented by CD1 activate subsets of lipid-reactive T cells in a TCR-restricted manner. Thus, group 1 CD1 presents lipid antigens to CD1a-, 
CD1b-, and CD1c-restricted T cells, whereas group 2 CD1 presents lipids to CD1drestricted NKT cells (Porcelli et al., 1989, 1992; Balk et al., 1991; Blumberg et al., 1991; Beckman et al., 1994; Kawano et al., 1997).

\section{CD1d-restricted NKT cells}

CD1d-restricted NKT cells are distinguished, based on their TCR expression, into invariant and non-invariant NKT cells, which differ with regard to the antigens recognized and the functions exerted. Invariant, or type I, NKT cells are characterized by the expression of a semi-invariant TCR composed of Va14-Ja18 in mice and Va24-Ja18 in humans, paired with a limited set of V $\beta$ chains (Bendelac et al., 2007). iNKT cells recognize the marine sponge glycolipid a-GalCer and can be directly detected using CD1dtetramers loaded with this lipid (Matsuda et al., 2000), which has provided unique insight into the phenotype and function of this NKT cell subset. iNKT cells exhibit coexpression of T-cell and NK-cell markers and are characterized by an effector memory phenotype (Bendelac et al., 2007). In accordance with these phenotypic characteristics, iNKT cells exhibit rapid, innate-like activation and secrete abundant amounts of $\mathrm{T}_{\mathrm{H}} 1$ [interferon (IFN) $\gamma$ ], $\mathrm{T}_{\mathrm{H}} 2$ [interleukin (IL) 4,13 , and 10], and $\mathrm{T}_{\mathrm{H}} 17$ cytokines (IL-17) with broad effects on other innate and adaptive immune cells and central roles in antimicrobial and cancer immunity as well as the regulation of autoimmunity and metabolism (Bendelac et al., 2007; Brennan et al., 2013).

Non-invariant, or type II, NKT cells are also CD1d-restricted but do not express the semiinvariant TCR. Compared with iNKT cells, less is known about non-invariant NKT cells due to the lack of specific markers for these cells. Initial studies on non-invariant NKT cells in MHC class II-deficient mice as well as subsequent studies on a subset of non-invariant NKT cells that recognize sulfatide revealed an oligoclonal TCR repertoire with predominant usage of V $\beta 8$ paired with a limited number of different Va chains (Va8, Va3, and Va1) (Cardell et al., 1995; Park et al., 2001; Arrenberg et al., 2010). In addition to differences in the TCR repertoire between invariant and non-invariant NKT cells, the antigens recognized by these cells (see above), the mode of their recognition, and the phenotype and function of NKT cell subsets are distinct. Thus, the ternary complex of CD1d, sulfatide, and the non-invariant NKT-TCR revealed fundamental differences in interaction compared with the iNKT-CD1d complex (Girardi et al., 2012; Patel et al., 2012). Specifically, the type I NKT-TCR adopts a tilted and parallel docking mode over the $\mathrm{F}^{\prime}$-pocket of CD1d, whereas the type II NKT-TCR docked diagonally above the A'-pocket of CD1d (Girardi et al., 2012; Patel et al., 2012). Functionally, non-invariant NKT cells lack constitutive expression of the early activation marker CD69 and exhibit regulatory actions in part through suppression of iNKT cell activation (Terabe et al., 2000; Jahng et al., 2004; Halder et al., 2007; Berzofsky and Terabe, 2009; Arrenberg et al., 2010). However, LPE-reactive non-invariant NKT cells can support anti-microbial immunity both directly via IFN- $\gamma$ secretion and indirectly via activation of iNKT cells and conventional T cells, suggesting the presence of functional heterogeneity even within the non-invariant NKT cell subset (Zeissig et al., 2012). Finally, additional complexity is provided by the recent discovery of atypical NKT cell subsets, which are aGalCer/CD1d-tetramer-reactive, but do not express murine Va14 or human Va24 (Constantinides et al., 2011; Uldrich et al., 2011). 


\section{Group 1 CD1-restricted T cells}

In contrast to NKT cells, group $1 \mathrm{CD} 1$-restricted $\mathrm{T}$ cells do not exist in mice due to the lack of CD1a, CD1b, and CD1c. For this reason, functional studies of group $1 \mathrm{CD} 1$-restricted T cells were initially limited to the analysis of $\mathrm{T}$ cell clones expanded from human peripheral blood. These studies revealed that group $1 \mathrm{CD} 1$-restricted T cells express either $\alpha \beta$ - or $\gamma \delta$ TCRs, can be grouped based on co-receptor expression into $\mathrm{CD} 4^{+}, \mathrm{CD} 8^{+}$, or doublenegative $\mathrm{T}$ cells, and consistently secrete IFN- $\gamma$ upon activation, whereas secretion of $\mathrm{T}_{\mathrm{H}} 2$ and $\mathrm{T}_{\mathrm{H}} 17$ cytokines exhibits significant $\mathrm{CD} 1$ isoform-dependent and inter-individual variation (Porcelli et al., 1989; Vincent et al., 2005; de Jong et al., 2010; de Lalla et al., 2011). Further, these cells resemble conventional MHC class I- and II-restricted T cells rather than iNKT cells in that they express a diverse TCR Va and V $\beta$ repertoire and, at least in peripheral blood, express markers characteristic of naive T cells (Grant et al., 1999; Vincent et al., 2005; de Jong et al., 2010; de Lalla et al., 2011). Similar to conventional MHC class I- and II-restricted T cells, the ratio of memory to naive group 1 CD1-restricted $\mathrm{T}$ cells increases from birth to adulthood with an increased percentage of cells expressing memory markers in peripheral tissues, suggesting antigen-dependent, activation-induced transition from naive to memory phenotype (de Jong et al., 2010; de Lalla et al., 2011).

Although studies of group $1 \mathrm{CD} 1$-restricted $\mathrm{T}$ cell clones provided critical insight into the mechanisms of TCR-dependent recognition of foreign lipid antigens, it remained unclear whether the phenotype, function, and frequency of group 1 CD1-restricted T cells within these clonal populations reflected the situation found in vivo. The development of group 1 CD1 tetramers therefore represented a major breakthrough in the field because it provided the opportunity to directly detect group $1 \mathrm{CD} 1$-restricted $\mathrm{T}$ cells among peripheral blood mononuclear cells (Kasmar et al., 2011; Ly et al., 2013; Van Rhijn et al., 2013). These studies revealed that $\mathrm{T}$ cells recognizing mycobacterial lipids in the context of $\mathrm{CD} 1 \mathrm{~b}$ and $\mathrm{CD} 1 \mathrm{c}$ can be detected among polyclonal $\mathrm{T}$ cells in peripheral blood, whereas CD1brestricted autoreactivity is not observed in contrast to CD1a (de Jong et al., 2010; de Lalla et al., 2011; Van Rhijn et al., 2013). Moreover, this work led to the recognition of an invariant CD1b-restricted germline-encoded, mycolyl lipid-reactive (GEM) T cell subset expressing a semi-invariant TCR composed of TRAV1-2 and TRAJ9 paired with a limited set of V $\beta$ chains (Van Rhijn et al., 2013). Despite the expression of a semi-invariant TCR, GEM T cells are phenotypically and functionally distinct from iNKT cells in that they do not consistently express the NK-cell marker CD161, lack baseline expression of the activation marker CD69, and are increased in numbers in patients with tuberculosis in accordance with infection-induced expansion of GEM T cells (Van Rhijn et al., 2013). In addition, recently developed group $1 \mathrm{CD} 1$ transgenic mice confirmed that group 1-restricted $\mathrm{T}$ cells resemble conventional $\mathrm{T}$ cells rather than iNKT cells and exhibit delayed immune responses and infection-induced expansion (Felio et al., 2009).

In conclusion, pioneering studies of lipid-reactive $\mathrm{T}$ cell clones and the recent development of group $1 \mathrm{CD} 1$ tetramers and transgenic mice (see below) provided critical insight into the biology of CD1a-, CD1b-, and CD1c-restricted T cells. This work revealed that group 1 CD1-restricted $\mathrm{T}$ cells phenotypically and functionally resemble conventional $\mathrm{T}$ cells rather than iNKT cells and recognize a wide variety of mycobacterial lipid antigens. Future studies 
using tetramers and animal models will be important to obtain further insight into the frequency, TCR repertoire, and function of CD1a-, CD1b-, and CD1c-restricted T cells in vivo.

\section{Antigen-dependent and antigen-independent pathways to activation of CD1-restricted (NK)T cells}

Antigen-dependent and antigen-independent pathways to CD1-restricted, (NK)T celldependent immunity have been described (Figure 3). As such, a large number of microbial lipids can bind to $\mathrm{CD} 1$ and activate $\mathrm{CD} 1$-restricted $\mathrm{T}$ cells in vitro and in vivo, thus providing the basis for antigen-driven, CD1-restricted antimicrobial immune responses (Figure 3, left). In addition, CD1 expression can be modulated upon infection, which can either facilitate antigen presentation through upregulation of $\mathrm{CD} 1$ or contribute to immune evasion through interference with this process (Amprey et al., 2004; Shinya et al., 2004; Berntman et al., 2005; Cho et al., 2005; Hage et al., 2005; Lin et al., 2005; Renukaradhya et al., 2005; Sanchez et al., 2005; Skold et al., 2005; Chen et al., 2006; Raghuraman et al., 2006; Yuan et al., 2006; Donovan et al., 2007; Kawana et al., 2007; Raftery et al., 2008).

Moreover, microbial exposure can affect the CD1 self-lipid repertoire and its antigenicity, thereby contributing to protective antimicrobial immunity through (NK)T cell activation (De Libero et al., 2005; Paget et al., 2007; Salio et al., 2007; Muindi et al., 2010; Brennan et al., 2011; Zeissig et al., 2012).

In addition to direct, antigen-dependent activation of lipid-reactive $\mathrm{T}$ cells, indirect cytokinedriven mechanisms exist, which promote the activation of CD1d-restricted iNKT cells independent of microbial lipid antigens. Thus, recognition of microbe-associated microbial patterns (MAMPs) through pattern recognition receptors such as TLRs and dectin 1 on dendritic cells (DCs) is associated with production of TLR4-dependent IL-12 and IL-18, dectin 1-dependent IL-12, and TLR9-dependent IL-12 and type I IFN. These cytokines potently activate iNKT cells, which is further enhanced by CD1d-restricted presentation of self-lipid antigens (Figure 3, second from left) (Brigl et al., 2003, 2011; Mattner et al., 2005; Montoya et al., 2006; Brennan et al., 2011; Cohen et al., 2011). Depending on the context, cytokines can be sufficient for indirect stimulation of iNKT cells, even in the absence of CD1d signals (Figure 3, second from right) (Nagarajan and Kronenberg, 2007; Tyznik et al., 2008). In addition to these mechanisms, TLR engagement and APC- and iNKT celldependent cytokine secretion promote CD1d-restricted antigen presentation through differentiation and maturation of DCs (Fujii et al., 2003; Hermans et al., 2003, 2007; Hegde et al., 2007). Cytokine-mediated iNKT cell activation thus enables iNKT cell-dependent recognition of bacteria and viruses devoid of CD1d-restricted lipid antigens and provides a mechanistic explanation for broad, iNKT cell-dependent immune responses against a wide variety of bacterial, viral, fungal, and protozoan pathogens. Moreover, lipid antigen- and cytokine-dependent pathways of iNKT cell activation are not exclusive but act together in iNKT cell-mediated antimicrobial immune responses in vivo. Thus, even in the case of infection with microbes containing antigenic CD1d lipids, cytokine-mediated stimulation of iNKT cells critically contributes to the overall immune response (Brigl et al., 2003, 2011). 
Finally, neurotransmitters may provide a third pathway to iNKT cell activation in addition to antigen- and cytokine-dependent mechanisms (Figure 3, right) (Wong et al., 2011).

In conclusion, the activation of lipid-reactive (NK)T cells in infection is facilitated by regulation of $\mathrm{CD} 1$ expression, alterations in the $\mathrm{CD} 1$ self-lipid profile, modulation of APC function, and antigen- and cytokine-dependent iNKT cell activation.

\section{Murine studies of lipid-reactive T cells in immunity, cancer, and metabolism}

Our knowledge of the physiological and pathophysiological roles of lipid-reactive $\mathrm{T}$ cells is largely based on the study of CD1d-restricted NKT cells in mice. These studies revealed that NKT cells play critical roles in antimicrobial immunity, cancer immunosurveillance, the modulation of immune-mediated or autoimmune diseases, and the regulation of lipid and carbohydrate metabolism. Selective aspects of the functions of NKT cells and group 1 CD1restricted $\mathrm{T}$ cells in immunity are discussed in the following sections. A more comprehensive description of this topic has been provided by several excellent, recent reviews (Berzofsky and Terabe, 2009; Cohen et al., 2009; Kinjo and Kronenberg, 2009; Vivier et al., 2012; Brennan et al., 2013).

\section{NKT cells in antimicrobial immunity}

Protective as well as pathogenic roles of NKT cells have been described in the immune response to a large number of bacterial, viral, fungal, and protozoan infections and in a subset of cases, direct, antigen-driven and indirect, cytokine-mediated NKT cell activation could be delineated (Tupin et al., 2007; Cohen et al., 2009). Thus, microbial-derived, CD1drestricted lipid antigens implicated in antimicrobial immunity were found in Sphingomonas spp. (Kinjo et al., 2005; Mattner et al., 2005; Sriram et al., 2005), B. burgdorferi (Kinjo et al., 2006), S. pneumoniae, group B Streptococcus (Kinjo et al., 2011), Mycobacterium tuberculosis (Fischer et al., 2004; Tatituri et al., 2013), H. pylori (Chang et al., 2011), L. donovani (Amprey et al., 2004), and E. histolytica (Lotter et al., 2009). In contrast, TLRinduced cytokine-driven responses mediate iNKT cell activation in response to bacteria and viruses devoid of lipid antigens and also contribute to immunity against bacteria containing CD1d-restricted lipid antigens (Brigl et al., 2003, 2011; Mattner et al., 2005; Montoya et al., 2006; Nagarajan and Kronenberg, 2007; Tyznik et al., 2008). Another example of combined direct and indirect effects on NKT cell activation is HBV infection, where early HBVinduced alterations in the self-lipid repertoire are recognized by a subset of non-invariant NKT cells, which consequently leads to broad, IL-12-dependent activation of other immune cells including iNKT cells (Zeissig et al., 2012).

Although a vast number of studies aimed at the delineation of the roles of invariant and noninvariant NKT cells in antimicrobial immunity, these studies were based on comparative analysis of CD1d- and Ja18-deficient mice and may need reassessment given the recent discovery of unanticipated, broad defects in the TCR repertoire of Ja18 knockout mice (Bedel et al., 2012). CD1d knockout mice $\left(C d 1 d 1^{-/-} C d 1 d 2^{-/-}\right)$lack both invariant and noninvariant NKT cells due to loss of CD1d-restricted positive selection in the thymus (Chen et al., 1997; Gapin et al., 2001; Benlagha et al., 2005). In contrast, Ja 18 knockout mice exhibit a deletion of the Ja segment of the semi-invariant iNKTCR (Traj18-/-) and were developed 
to selectively delete iNKT cells (Cui et al., 1997). However, a recent study revealed that Ja18 knockout mice exhibit an unanticipated loss of a significant fraction of Ja regions associated with lack of about $60 \%$ of TCRa diversity (Bedel et al., 2012). Impaired immunity in Traj18 $18^{-/-}$mice may therefore relate to lack of iNKT cells as well as defects in the conventional $\mathrm{T}$ cell repertoire, which limits conclusions derived from the study of these mice. For these reasons, the relative contributions of invariant and non-invariant NKT cells to antimicrobial immunity are largely unclear at present.

Finally, in accordance with the critical role of NKT cells in antimicrobial immunity, immune evasion strategies exist, particularly for viral agents. Thus, HIV infection is associated with internalization and trans-Golgi retention of CD1d in a manner dependent on the HIV Nef and gp120 proteins (Cho et al., 2005; Hage et al., 2005; Chen et al., 2006). Moreover, HIV infection is associated with NKT cell exhaustion through the modulation of PD-1 expression and PD-1-independent pathways (Moll et al., 2009). Similar observations of evasion of CD1drestricted immunity have been made for other viruses such as lymphocytic choriomeningitis virus, vesicular stomatitis virus, herpes simplex virus, Kaposi sarcomaassociated herpesvirus and bacteria including Leishmania and Chlamydia species (Lin et al., 2005; Sanchez et al., 2005; Raftery et al., 2006; Yuan et al., 2006; Kawana et al., 2007; Renukaradhya et al., 2008).

\section{NKT cells in cancer immunosurveillance}

a-GalCer, a marine sponge-derived GSL, was originally identified in a screen for tumormodulating compounds, where it was associated with protection in the B16 melanoma model (Kobayashi et al., 1995; Motoki et al., 1996). a-GalCer was later demonstrated to act through the activation of iNKT cells and to suppress tumor development in an IFN- $\gamma$ - and IL-12-dependent manner (Kawano et al., 1997; Kitamura et al., 1999). In addition, related ceramide-based lipids such as $\beta$-mannosylceramide elicit similar antioncogenic actions but act through independent iNKT cell-mediated pathways dependent on TNF- $a$ and nitric oxide (O'Konek et al., 2011). Even in the absence of exogenous, stimulatory lipid antigens, iNKT cells contribute to natural immunosurveillance in solid and hematopoietic cancers including fibrosarcoma induced by methylcholanthrene (Smyth et al., 2000; Crowe et al., 2002, 2005), adenocarcinomas, sarcomas, and hematopoietic tumors induced by loss of p53 (Swann et al., 2009), colorectal cancer (Yoshioka et al., 2012), hepatocellular carcinoma (Anson et al., 2012), and neuroblastoma (Song et al., 2009). Studies in neuroblastoma also revealed that iNKT cells may not only interfere with tumor growth through direct tumor cell cytotoxicity but can act indirectly through killing of tumor-associated, oncogenic macrophages (Song et al., 2009). Although initial cancer studies were performed in Ja18 knockout mice, with limitations as described above, CD1d-deficient mice exhibited a similar phenotype, and the transfer of total NKT cells or purified iNKT cells was associated with protection thus supporting a role of iNKT cells in anticancer immunity (Crowe et al., 2002, 2005; Song et al., 2009; Izhak et al., 2013). One remarkable exception to the rule of anti-oncogenic effects of iNKT cells is the model of azoxymethane/oxazolone-induced colitisassociated colorectal cancer, which is mediated by iNKT cells in a process dependent on IL-13 secretion, induction of CD11 b $\mathrm{b}^{\text {hi }} \mathrm{Gr} 1^{\text {low }}$ macrophages, and transforming growth factor- $\beta$ (TGF- $\beta$ )dependent suppression of tumor immunosurveillance (Schiechl et al., 2011). 
In contrast to protective roles of iNKT cells, non-invariant NKT cells were suggested to contribute to tumor growth in an oncogenic manner in models of fibrosarcoma as well as mammary, colorectal, and renal cell carcinoma (Terabe et al., 2000, 2003; Izhak et al., 2013). These actions were mediated by IL-13-induced expression of TGF- $\beta$ by CD $11 b^{+}$ Gr- $1^{+}$cells and suppression of tumor-specific CD8 ${ }^{+} \mathrm{T}$ cells (Terabe et al., 2000, 2003; Izhak et al., 2013). In the majority of these studies, the protective effects of CD1d deletion were ascribed to the loss of non-invariant NKT cells, as tumor development in Ja18-deficient mice resembled that observed in wildtype mice. Although the defects in the conventional TCR repertoire may have affected tumor cell growth, recent studies based on selective activation of invariant and non-invariant NKT cell subsets and reconstitution of iNKT cells in Ja18-deficient mice revealed similar results and support the concept of opposing roles of NKT cell subsets in cancer (Izhak et al., 2013). Noteworthy, invariant and non-invariant NKT cell subsets cross-regulate each other not only in terms of function but also frequency, thus adding another layer of complexity to the role of NKT cells in malignancy (Izhak et al., 2013).

Although the aforementioned studies were performed in mice, indirect evidence suggests similar roles of NKT cells in human malignancy. Thus, iNKT cell infiltration in colorectal cancer and neuroblastoma correlates with increased survival (Metelitsa et al., 2004; Tachibana et al., 2005), whereas low levels of circulating iNKT cells predict poor clinical outcomes in head and neck squamous cell carcinoma (Molling et al., 2007). Moreover, iNKT cells obtained from human cancer patients exhibit impaired proliferative responses, decreased secretion of IFN- $\gamma$, and an increased ratio of regulatory IL-4 to anti-oncogenic IFN- $\gamma$ (Tahir et al., 2001; Yanagisawa et al., 2002; Dhodapkar et al., 2003; Bricard et al., 2009).

Given the protective roles of iNKT cells in oncogenesis, therapeutic modulation of NKT cells has been investigated in human malignancy. Direct injection of a-GalCer into patients with solid tumors proved largely unsuccessful due to limited iNKT cell responses (Giaccone et al., 2002). Subsequent approaches included the transfer of a-GalCer-pulsed autologous DCs, which was also associated with considerable, inter-individual variation in the response observed (Ishikawa et al., 2005; Motohashi et al., 2006, 2009; Uchida et al., 2008; Nagato et al., 2012). Therefore, combination therapy may be required for efficacious NKT cell-based immunotherapy in cancer. In accordance with this concept, a subset of patients with multiple myeloma exhibited tumor regression upon treatment with a-GalCer-loaded dendritic cells in combination with lenalidomide (Richter et al., 2013).

Together, these studies demonstrate a critical role of NKT cells in tumor development and warrant further optimization of NKT cell-based immunotherapy in human malignancy.

\section{NKT cells in the regulation of immune-mediated diseases}

NKT cells were suggested to contribute to a variety of human immune-mediated diseases and their murine models including type I diabetes, multiple sclerosis, rheumatoid arthritis, systemic lupus erythematosus, autoimmune hepatitis, primary biliary cirrhosis, sarcoidosis, asthma, and inflammatory bowel disease (IBD). Owing to the complexity of this field and 
the controversies that have arisen (Subleski et al., 2011), we will focus on the role of NKT cells in IBD, where recent studies have provided critical insight into the regulation of mucosal immune responses by NKT cells at the interface between the host and the environment.

We and others could demonstrate that NKT cells play critical roles in human IBD and mouse models of intestinal inflammation (Saubermann et al., 2000; Heller et al., 2002; Fuss et al., 2004; Zeissig et al., 2007; Schiechl et al., 2011; Camelo et al., 2012; Olszak et al., 2012). Thus, oxazolone colitis, a model of human ulcerative colitis (UC), is dependent on CD1d and CD1d-restricted NKT cells (Heller et al., 2002; Schiechl et al., 2011; Olszak et al., 2012). Similar findings were made for human UC, where key pathogenic cytokines such as IL-13 originate from NKT cells and contribute to impaired epithelial barrier function and sustained intestinal inflammation (Fuss et al., 2004; Heller et al., 2005). Although studies in oxazolone colitis reported a central, pathogenic role of iNKT cells (Heller et al., 2002), this work was based on Ja18-deficient mice and is associated with the respective limitations outlined above (Bedel et al., 2012). In contrast, pathogenic IL-13 in human UC originates from a-GalCer/CD1d-tetramer-negative T cells and thus presumably non-invariant NKT cells (Fuss et al., 2004). In accordance with a predominant role of non-invariant NKT cells in intestinal inflammation, transgenic expression of a non-invariant TCR led to spontaneous intestinal inflammation in mice, particularly in the presence of overexpression of CD1d (Liao et al., 2012). The biological relevance of these findings is highlighted by the fact that genetic polymorphisms associated with susceptibility to IBD relate to genes enriched in expression by NKT cells (Jostins et al., 2012). Further, a variety of genes with critical roles in lipid metabolism have been highlighted by expression analysis and genome-wide association studies in IBD and may at least partially contribute to disease susceptibility through modulation of the activation of lipid-reactive T cells (Jostins et al., 2012; Planell et al., 2013). Finally, a randomized, placebo-controlled, multicenter study recently revealed the efficacy of oral PC in UC (Karner et al., 2012). Given that PC binds to CD1d but does not activate human NKT cells (Fox et al., 2009), interference with CD1d-restricted mucosal NKT cell activation may contribute to the therapeutic efficacy of PC, a concept that awaits verification.

It has recently been demonstrated that intestinal inflammation in oxazolone colitis is not dependent on microbial antigens as germfree mice exhibited increased rather than decreased intestinal inflammation (Olszak et al., 2012). These findings suggest that a yet to be identified self-antigen may initiate and mediate chronic, NKT cell-dependent intestinal inflammation. Moreover, these studies revealed that exposure to the intestinal microbiota during early but not adult life leads to a persistent decrease in intestinal iNKT cell numbers and protection from NKT cell-mediated intestinal inflammation during adult life (Olszak et al., 2012). The microbiota therefore plays critical roles in the modulation of NKT cells at mucosal surfaces, a phenomenon similarly observed in the lung (Olszak et al., 2012). Future studies will be required to delineate the cellular origin and the nature of presumed selfantigens, which initiate NKT cell-dependent inflammation at mucosal surfaces. Similarly, antigen-dependent and antigen-independent environmental modulators of postnatal, mucosal NKT cell development await further characterization. 


\section{NKT cells in the regulation of lipid and carbohydrate metabolism}

NKT cells are affected by dysregulation of lipid metabolism and, conversely, also actively control lipid and carbohydrate metabolism, thus reflecting a bidirectional process of regulation. Moreover, NKT cells modulate disorders at the interface of metabolism and inflammation such as obesity, metabolic syndrome, and non-alcoholic fatty liver disease (NAFLD). Thus, obesity is associated with reduced numbers of iNKT cells in peripheral blood, liver, and adipose tissue in humans and mice, whereas weight loss leads to increasing numbers of peripheral iNKT cells (Guebre-Xabier et al., 2000; Lynch et al., 2009, 2012; Kotas et al., 2011; Ji et al., 2012). Moreover, NAFLD is associated with reduced CD1d expression by hepatocytes and impaired hepatocyte-dependent iNKT cell activation (Yang et al., 2007).

In accordance with bidirectional regulation of NKT cells and lipid metabolism, CD1d and Ja18 deficiency in mice, independent of low- or high-fat diet, is associated with adipocyte hypertrophy, increased leptin as well as decreased adiponectin levels, and insulin resistance (Lynch et al., 2012; Schipper et al., 2012). On a high fat diet, CD1d- and Ja18-deficient mice also exhibit increased weight gain and hepatic steatosis (Lynch et al., 2012). In further support of a mechanistic link between iNKT cells and the regulation of glucose and lipid metabolism, transfer of iNKT cells or a-GalCer treatment was associated with reduced adipocyte size, decreased leptin and increased adiponectin levels, increased M2 macrophage polarization, anti-inflammatory IL-10 and IL-4 signaling, and improved insulin sensitivity (Ji et al., 2012; Lynch et al., 2012). Importantly, both hepatocytes and adipocytes express CD1d and can activate iNKT cells in a CD1d-restricted manner (Yang et al., 2007; Schipper et al., 2012). This raises the possibility that obesity-induced alterations in the adipocyte and hepatocyte CD1d self-lipid repertoire may regulate metabolism and obesity-associated inflammation via modulation of iNKT cell activation. Although differences in the extent and outcome of iNKT cell-mediated metabolic modulation were observed between studies (Mantell et al., 2011; Wu et al., 2012), these discrepancies may relate to differences in the intestinal microbiota, which is modulated by host metabolism and regulates iNKT cell function (Olszak et al., 2012; Tremaroli and Backhed, 2012; Wingender et al., 2012).

Together, these studies demonstrate a tight connection between metabolism and immunity and reveal a central role of lipid-reactive $\mathrm{T}$ cells in the bidirectional regulation of this process.

\section{Murine studies of group 1 CD1-restricted T cells in immunity}

Although a large number of studies in rodent models characterized the role of CD1drestricted NKT cells in vivo, similar studies of CD1a-, CD1b-, and CD1c-restricted T cells were prevented by the lack of group $1 \mathrm{CD} 1$ expression in mice. Our understanding of the function of group $1 \mathrm{CD} 1$-restricted $\mathrm{T}$ cells is therefore largely based on the analysis of human $\mathrm{T}$ cell clones. These studies revealed the recognition of various mycobacterial lipid antigens by group $1 \mathrm{CD} 1$-restricted $\mathrm{T}$ cells, suggesting a potential role of these cells in immunity to mycobacteria and particularly to M. tuberculosis (Moody et al., 2005; Cohen et al., 2009). 
The recent development of mice with transgenic expression of human group $1 \mathrm{CD} 1$ provided a crucial step toward the characterization of CD1a-, CD1b-, and CD1c-restricted T cells in vivo (Felio et al., 2009). Initial studies in these mice demonstrated that group 1 CD1restricted $\mathrm{T}$ cells both phenotypically and functionally resemble conventional $\mathrm{T}$ cells rather than iNKT cells and exhibit delayed immune responses (Felio et al., 2009). In accordance with previous ex vivo and in vitro studies, which suggested a central role of CD1a, CD1b, and $\mathrm{CD} 1 \mathrm{c}$ in the recognition of $M$. tuberculosis, infection of transgenic mice induced group 1 CD1-restricted T cell responses directed against $M$. tuberculosis with T cell-dependent recognition of previously characterized M. tuberculosis-derived lipids (Felio et al., 2009). Interestingly, preliminary studies revealed that clearance of $M$. tuberculosis did not differ between mice with and without group 1 CD1 expression. Further studies are therefore required to delineate the contribution of group $1 \mathrm{CD} 1$ to the immune response against $M$. tuberculosis and other microorganisms and to define potential roles of CD1a-, CD1b-, and CD1c-restricted T cells in the modulation of autoimmunity, cancer immunosurveillance, and the regulation of metabolic function.

\section{The biological role of lipid-reactive T cells in human immunity}

Murine studies revealed a critical role of CD1d-restricted NKT cells in antimicrobial immunity and demonstrated susceptibility of CD1d-deficient mice to a vast number of microorganisms (Tupin et al., 2007; Brennan et al., 2013). However, similar observations of broad immunodeficiency were made in mice deficient in TLRs, TLR adaptors, and NK cells, whereas patients carrying mutations in these pathways exhibited few, selected immune defects (Orange, 2002; Zhang et al., 2007; von Bernuth et al., 2008). These studies therefore suggested that the immune response in inbred mice may not fully recapitulate human immunity - a finding recently confirmed in a systematic approach (Casanova and Abel, 2007; Seok et al., 2013).

To define the role of CD1 in human immunity, patients with the rare Mendelian disorder abetalipoproteinemia (ABL) were studied. ABL is characterized by mutations in MTP, an ER-resident lipid transfer protein involved in the generation of apolipoprotein B (ApoB)containing lipoprotein particles (Wetterau et al., 1992; Berriot-Varoqueaux et al., 2000; Abumrad and Davidson, 2012). Due to deficiency in MTP, ABL patients exhibit defects in the secretion of chylomicrons and very low-density lipoprotein, which is associated with hypolipidemia and severe neurological defects (Berriot-Varoqueaux et al., 2000; Abumrad and Davidson, 2012). In addition to its role in lipoprotein metabolism, MTP can directly transfer phospholipids onto CD1d and is critical for the function of group 1 and group 2 CD1 (Brozovic et al., 2004; Dougan et al., 2005, 2007; Kaser et al., 2008). Accordingly, these studies revealed broad defects in group 1 and group $2 \mathrm{CD} 1$ function in ABL (Zeissig et al., 2010). Group $1 \mathrm{CD} 1$, particularly CD1a and CD1c, underwent proteasomal degradation in patients with $\mathrm{ABL}$, possibly as a consequence of impaired ligand-dependent CD1 stabilization, a fate similarly observed for apolipoprotein B (ApoB) (Berriot-Varoqueaux et al., 2000; Zeissig et al., 2010). CD1d escaped proteasomal degradation and showed normal cell surface expression but was unable to load and present exogenous lipid antigens and did not elicit NKT cell auto-reactivity. Consequently, iNKT cells were either not detectable or showed severe phenotypic alterations in ABL. In contrast to CD1, MHC class I- and class II- 
restricted antigen presentation and conventional $\mathrm{T}$ - and $\mathrm{B}$-cell function were unaltered. $\mathrm{ABL}$ is thus characterized by selective and severe defects in CD1 and provides a unique opportunity to study the biological relevance of CD1-restricted (NK)T cells.

Although fewer than 100 patients with ABL have been clinically characterized, several cases of heart failure due to lesions resembling chronic interstitial myocarditis, fatal pulmonary infections, and rare malignancies have been described in ABL (Berriot-Varoqueaux et al., 2000). Given the central role of NKT cells in immunity to pulmonary and cardiotropic microbial pathogens as well as cancer immunity in mice, these findings support the concept of immunerelated defects due to deficiency in MTP and CD1 (Zeissig et al., 2010; Zeissig and Blumberg, 2012). However, the spectrum of immune defects in ABL is remarkably restricted, which contrasts with observations in CD1d-deficient mice. Although such conclusions are limited to frequently encountered microorganisms given the low incidence of ABL, they reflect findings made for human and murine TLR and NK cell deficiency as outlined above (Orange, 2002; Zhang et al., 2007; von Bernuth et al., 2008). Together, these observations suggest that CD1-restricted (NK)T cells have critical and indispensable contributions to human and murine immunity but that mechanisms that compensate for the loss of functional CD1 prevent broad immunodeficiency, at least in humans.

\section{Concluding remarks}

Significant insight into the role of lipid-reactive T cells has been gained over the past 25 years. As such, antigen-dependent and antigen-independent pathways to the activation of lipid-reactive $\mathrm{T}$ cells were described, a large number of self and microbial lipid antigens were identified, and the roles of lipid-reactive $\mathrm{T}$ cells in immunity were characterized. Despite these significant advances, however, further studies are required to characterize the dynamics of the CD1 lipidome in health and disease, to gain further insight into the physiological role of group 1 CD1-restricted T cells in vivo, to delineate the functions of invariant and non-invariant NKT cells, and to define the mechanisms of NKT cell activation in autoimmune diseases and cancer and their modulation by environmental influences such as the microbiota.

\section{Acknowledgments}

We apologize that due to constraints in the length of this manuscript and the number of citations, we had to focus on selected aspects of CD1 biology and could only highlight few, selected studies. Experimental studies by the authors were supported by the Deutsche Forschungsgemeinschaft (DFG) (ZE 814/1-1, 2-1, 4-1; DFG Cluster 'Inflammation at Interfaces') and the European Commission (Marie-Curie International Reintegration Grant, FP7) (S.Z.); NIH grants DK044319, DK051362, DK053056, and DK088199; the Harvard Digestive Diseases Center (HDDC) (DK0034854) (R.S.B.).

\section{References}

Abumrad NA, Davidson NO. Role of the gut in lipid homeostasis. Physiol. Rev. 2012; 92:1061-1085. [PubMed: 22811425]

Amprey JL, Im JS, Turco SJ, Murray HW, Illarionov PA, Besra GS, Porcelli SA, Spath GF. A subset of liver NK T cells is activated during Leishmania donovani infection by CD1d-bound lipophosphoglycan. J. Exp. Med. 2004; 200:895-904. [PubMed: 15466622] 
Anson M, Crain-Denoyelle AM, Baud V, Chereau F, Gougelet A, Terris B, Yamagoe S, Colnot S, Viguier $\mathrm{M}$, Perret $\mathrm{C}$, et al. Oncogenic $\beta$-catenin triggers an inflammatory response that determines the aggressiveness of hepatocellular carcinoma in mice. J. Clin. Invest. 2012; 122:586-599. [PubMed: 22251704]

Arrenberg P, Halder R, Dai Y, Maricic I, Kumar V. Oligoclonality and innate-like features in the TCR repertoire of type II NKT cells reactive to a $\beta$-linked self-glycolipid. Proc. Natl. Acad. Sci. USA. 2010; 107:10984-10989. [PubMed: 20534460]

Balk SP, Ebert EC, Blumenthal RL, McDermott FV, Wucherpfennig KW, Landau SB, Blumberg RS. Oligoclonal expansion and CD1 recognition by human intestinal intraepithelial lymphocytes. Science. 1991; 253:1411-1415. [PubMed: 1716785]

Balk SP, Burke S, Polischuk JE, Frantz ME, Yang L, Porcelli S, Colgan SP, Blumberg RS. Beta 2microglobulin-independent MHC class Ib molecule expressed by human intestinal epithelium. Science. 1994; 265:259-262. [PubMed: 7517575]

Beckman EM, Porcelli SA, Morita CT, Behar SM, Furlong ST, Brenner MB. Recognition of a lipid antigen by CD1-restricted $\alpha \beta^{+}$T cells. Nature. 1994; 372:691-694. [PubMed: 7527500]

Bedel R, Matsuda JL, Brigl M, White J, Kappler J, Marrack P, Gapin L. Lower TCR repertoire diversity in Traj18-deficient mice. Nat. Immunol. 2012; 13:705-706. [PubMed: 22814339]

Bendelac A, Savage PB, Teyton L. The biology of NKT cells. Annu. Rev. Immunol. 2007; 25:297336. [PubMed: 17150027]

Benlagha K, Wei DG, Veiga J, Teyton L, Bendelac A. Characterization of the early stages of thymic NKT cell development. J. Exp. Med. 2005; 202:485-942. [PubMed: 16087715]

Berntman E, Rolf J, Johansson C, Anderson P, Cardell SL. The role of CD1d-restricted NK T lymphocytes in the immune response to oral infection with Salmonella typhimurium. Eur. J. Immunol. 2005; 35:2100-2109. [PubMed: 15940666]

Berriot-Varoqueaux N, Aggerbeck LP, Samson-Bouma M, Wetterau JR. The role of the microsomal triglygeride transfer protein in abetalipoproteinemia. Annu. Rev. Nutr. 2000; 20:663-697. [PubMed: 10940349]

Berzofsky JA, Terabe M. The contrasting roles of NKT cells in tumor immunity. Curr. Mol. Med. 2009; 9:667-672. [PubMed: 19689293]

Blumberg RS, Terhorst C, Bleicher P, McDermott FV, Allan CH, Landau SB, Trier JS, Balk SP. Expression of a nonpolymorphic MHC class I-like molecule, CD1D, by human intestinal epithelial cells. J. Immunol. 1991; 147:2518-2524. [PubMed: 1717564]

Brennan PJ, Tatituri RV, Brigl M, Kim EY, Tuli A, Sanderson JP, Gadola SD, Hsu FF, Besra GS, Brenner MB. Invariant natural killer T cells recognize lipid self antigen induced by microbial danger signals. Nat. Immunol. 2011; 12:1202-1211. [PubMed: 22037601]

Brennan PJ, Brigl M, Brenner MB. Invariant natural killer T cells: an innate activation scheme linked to diverse effector functions. Nat. Rev. Immunol. 2013; 13:101-117. [PubMed: 23334244]

Bricard G, Cesson V, Devevre E, Bouzourene H, Barbey C, Rufer N, Im JS, Alves PM, Martinet O, Halkic N, et al. Enrichment of human $\mathrm{CD}^{+} \mathrm{Va} 24 / \mathrm{V} \beta 11$ invariant NKT cells in intrahepatic malignant tumors. J. Immunol. 2009; 182:5140-5151. [PubMed: 19342695]

Brigl M, Bry L, Kent SC, Gumperz JE, Brenner MB. Mechanism of CD1d-restricted natural killer T cell activation during microbial infection. Nat. Immunol. 2003; 4:1230-1237. [PubMed: 14578883]

Brigl M, Tatituri RV, Watts GF, Bhowruth V, Leadbetter EA, Barton N, Cohen NR, Hsu FF, Besra GS, Brenner MB. Innate and cytokine-driven signals, rather than microbial antigens, dominate in natural killer T cell activation during microbial infection. J. Exp. Med. 2011; 208:1163-1177. [PubMed: 21555485]

Briken V, Jackman RM, Watts GF, Rogers RA, Porcelli SA. Human CD1b and CD1c isoforms survey different intracellular compartments for the presentation of microbial lipid antigens. J. Exp. Med. 2000; 192:281-288. [PubMed: 10899914]

Brozovic S, Nagaishi T, Yoshida M, Betz S, Salas A, Chen D, Kaser A, Glickman J, Kuo T, Little A, et al. CD1d function is regulated by microsomal triglyceride transfer protein. Nat. Med. 2004; 10:535-539. [PubMed: 15107843] 
Cala-De Paepe D, Layre E, Giacometti G, Garcia-Alles LF, Mori L, Hanau D, de Libero G, de la Salle H, Puzo G, Gilleron M. Deciphering the role of CD1e protein in mycobacterial phosphatidyl-myoinositol mannosides (PIM) processing for presentation by CD1b to T lymphocytes. J. Biol. Chem. 2012; 287:31494-31502. [PubMed: 22782895]

Camelo A, Barlow JL, Drynan LF, Neill DR, Ballantyne SJ, Wong SH, Pannell R, Gao W, Wrigley K, Sprenkle J, et al. Blocking IL-25 signalling protects against gut inflammation in a type-2 model of colitis by suppressing nuocyte and NKT derived IL-13. J. Gastroenterol. 2012; 47:1198-1211. [PubMed: 22539101]

Cardell S, Tangri S, Chan S, Kronenberg M, Benoist C, Mathis D. CD1-restricted CD4 ${ }^{+}$T cells in major histocompatibility complex class II-deficient mice. J. Exp. Med. 1995; 182:993-1004. [PubMed: 7561702]

Casanova JL, Abel L. Primary immunodeficiencies: a field in its infancy. Science. 2007; 317:617-619. [PubMed: 17673650]

Chang YJ, Kim HY, Albacker LA, Lee HH, Baumgarth N, Akira S, Savage PB, Endo S, Yamamura T, Maaskant J, et al. Influenza infection in suckling mice expands an NKT cell subset that protects against airway hyperreactivity. J. Clin. Invest. 2011; 121:57-69. [PubMed: 21157038]

Chen N, McCarthy C, Drakesmith H, Li D, Cerundolo V, McMichael AJ, Screaton GR, Xu XN. HIV-1 down-regulates the expression of CD1d via Nef. Eur. J. Immunol. 2006; 36:278-286. [PubMed: 16385629]

Chen YH, Chiu NM, Mandal M, Wang N, Wang CR. Impaired NK1+ T cell development and early IL-4 production in CD1-deficient mice. Immunity. 1997; 6:459-467. [PubMed: 9133425]

Chiu YH, Jayawardena J, Weiss A, Lee D, Park SH, Dautry-Varsat A, Bendelac A. Distinct subsets of CD1d-restricted T cells recognize self-antigens loaded in different cellular compartments. J. Exp. Med. 1999; 189:103-110. [PubMed: 9874567]

Chiu YH, Park SH, Benlagha K, Forestier C, Jayawardena-Wolf J, Savage PB, Teyton L, Bendelac A. Multiple defects in antigen presentation and $\mathrm{T}$ cell development by mice expressing cytoplasmic tail-truncated CD1d. Nat. Immunol. 2002; 3:55-60. [PubMed: 11731798]

Cho S, Knox KS, Kohli LM, He JJ, Exley MA, Wilson SB, Brutkiewicz RR. Impaired cell surface expression of human CD1d by the formation of an HIV-1 Nef/CD1d complex. Virology. 2005; 337:242-252. [PubMed: 15916790]

Cohen NR, Garg S, Brenner MB. Antigen presentation by CD1 lipids, T cells, and NKT cells in microbial immunity. Adv. Immunol. 2009; 102:1-94. [PubMed: 19477319]

Cohen NR, Tatituri RV, Rivera A, Watts GF, Kim EY, Chiba A, Fuchs BB, Mylonakis E, Besra GS, Levitz SM, et al. Innate recognition of cell wall $\beta$-glucans drives invariant natural killer $\mathrm{T}$ cell responses against fungi. Cell Host Microbe. 2011; 10:437-450. [PubMed: 22100160]

Constantinides MG, Picard D, Savage AK, Bendelac A. A naive-like population of human CD1drestricted T cells expressing intermediate levels of promyelocytic leukemia zinc finger. J. Immunol. 2011; 187:309-315. [PubMed: 21632718]

Cox D, Fox L, Tian R, Bardet W, Skaley M, Mojsilovic D, Gumperz J, Hildebrand W. Determination of cellular lipids bound to human CD1d molecules. PLoS One. 2009; 4:e5325. [PubMed: 19415116]

Crowe NY, Smyth MJ, Godfrey DI. A critical role for natural killer T cells in immunosurveillance of methylcho-lanthrene-induced sarcomas. J. Exp. Med. 2002; 196:119-127. [PubMed: 12093876]

Crowe NY, Coquet JM, Berzins SP, Kyparissoudis K, Keating R, Pellicci DG, Hayakawa Y, Godfrey DI, Smyth MJ. Differential antitumor immunity mediated by NKT cell subsets in vivo. J. Exp. Med. 2005; 202:1279-1288. [PubMed: 16275765]

Cui J, Shin T, Kawano T, Sato H, Kondo E, Toura I, Kaneko Y, Koseki H, Kanno M, Taniguchi M. Requirement for Va14 NKT cells in IL-12-mediated rejection of tumors. Science. 1997; 278:1623-1626. [PubMed: 9374462]

de Jong A, Pena-Cruz V, Cheng TY, Clark RA, Van Rhijn I, Moody DB. CD1a-autoreactive T cells are a normal component of the human $\alpha \beta$ T cell repertoire. Nat. Immunol. 2010; 11:1102-1109. [PubMed: 21037579] 
de la Salle H, Mariotti S, Angenieux C, Gilleron M, Garcia-Alles LF, Malm D, Berg T, Paoletti S, Maitre B, Mourey L, et al. Assistance of microbial glycolipid antigen processing by CD1e. Science. 2005; 310:1321-1324. [PubMed: 16311334]

de Lalla C, Lepore M, Piccolo FM, Rinaldi A, Scelfo A, Garavaglia C, Mori L, De Libero G, Dellabona P, Casorati G. High-frequency and adaptive-like dynamics of human CD1 self-reactive T cells. Eur. J. Immunol. 2011; 41:602-610. [PubMed: 21246542]

De Libero G, Moran AP, Gober HJ, Rossy E, Shamshiev A, Chelnokova O, Mazorra Z, Vendetti S, Sacchi A, Prendergast MM, et al. Bacterial infections promote T cell recognition of selfglycolipids. Immunity. 2005; 22:763-772. [PubMed: 15963790]

De Libero G, Collmann A, Mori L. The cellular and biochemical rules of lipid antigen presentation. Eur. J. Immunol. 2009; 39:2648-2656. [PubMed: 19728312]

Dhodapkar MV, Geller MD, Chang DH, Shimizu K, Fujii S, Dhodapkar KM, Krasovsky J. A reversible defect in natural killer $\mathrm{T}$ cell function characterizes the progression of premalignant to malignant multiple myeloma. J. Exp. Med. 2003; 197:1667-1676. [PubMed: 12796469]

Donovan MJ, Jayakumar A, McDowell MA. Inhibition of groups 1 and 2 CD1 molecules on human dendritic cells by Leishmania species. Parasite Immunol. 2007; 29:515-524. [PubMed: 17883454]

Dougan SK, Salas A, Rava P, Agyemang A, Kaser A, Morrison J, Khurana A, Kronenberg M, Johnson C, Exley M, Hussain MM, Blumberg RS. Microsomal triglyceride transfer protein lipidation and control of CD1d on antigen-presenting cells. J. Exp. Med. 2005; 202:529-539. [PubMed: 16087713]

Dougan SK, Rava P, Hussain MM, Blumberg RS. MTP regulated by an alternate promoter is essential for NKT cell development. J. Exp. Med. 2007; 204:533-545. [PubMed: 17312007]

Ernst WA, Maher J, Cho S, Niazi KR, Chatterjee D, Moody DB, Besra GS, Watanabe Y, Jensen PE, Porcelli SA, et al. Molecular interaction of CD1b with lipoglycan antigens. Immunity. 1998; 8:331-340. [PubMed: 9529150]

Facciotti F, Cavallari M, Angenieux C, Garcia-Alles LF, Signorino-Gelo F, Angman L, Gilleron M, Prandi J, Puzo G, Panza L, et al. Fine tuning by human CD1e of lipid-specific immune responses. Proc. Natl. Acad. Sci. USA. 2011; 108:14228-14233. [PubMed: 21844346]

Facciotti F, Ramanjaneyulu GS, Lepore M, Sansano S, Cavallari M, Kistowska M, Forss-Petter S, Ni G, Colone A, Singhal A, et al. Peroxisome-derived lipids are self antigens that stimulate invariant natural killer T cells in the thymus. Nat. Immunol. 2012; 13:474-480. [PubMed: 22426352]

Felio K, Nguyen H, Dascher CC, Choi HJ, Li S, Zimmer MI, Colmone A, Moody DB, Brenner MB, Wang CR. CD1-restricted adaptive immune responses to Mycobacteria in human group $1 \mathrm{CD} 1$ transgenic mice. J. Exp. Med. 2009; 206:2497-2509. [PubMed: 19808251]

Fischer K, Scotet E, Niemeyer M, Koebernick H, Zerrahn J, Maillet S, Hurwitz R, Kursar M, Bonneville M, Kaufmann SH, et al. Mycobacterial phosphati-dylinositol mannoside is a natural antigen for CD1d-restricted T cells. Proc. Natl. Acad. Sci. USA. 2004; 101:10685-10690. [PubMed: 15243159]

Florence WC, Xia C, Gordy LE, Chen W, Zhang Y, Scott-Browne J, Kinjo Y, Yu KO, Keshipeddy S, Pellicci DG, et al. Adaptability of the semi-invariant natural killer T-cell receptor towards structurally diverse CD1d-restricted ligands. EMBO J. 2009; 28:3781. [PubMed: 19953109]

Fox LM, Cox DG, Lockridge JL, Wang X, Chen X, Scharf L, Trott DL, Ndonye RM, Veerapen N, Besra GS, et al. Recognition of lyso-phospholipids by human natural killer T lymphocytes. PLoS Biol. 2009; 7:e1000228. [PubMed: 19859526]

Fuchs B, Muller K, Paasch U, Schiller J. Lysophospholipids: potential markers of diseases and infertility? Mini Rev. Med. Chem. 2012; 12:74-86. [PubMed: 22070693]

Fujii S, Shimizu K, Smith C, Bonifaz L, Steinman RM. Activation of natural killer T cells by alphagalactosyl-ceramide rapidly induces the full maturation of dendritic cells in vivo and thereby acts as an adjuvant for combined CD4 and CD8 T cell immunity to a coadministered protein. J. Exp. Med. 2003; 198:267-279. [PubMed: 12874260]

Fuss IJ, Heller F, Boirivant M, Leon F, Yoshida M, Fichtner-Feigl S, Yang Z, Exley M, Kitani A, Blumberg RS, et al. Nonclassical CD1d-restricted NK T cells that produce IL-13 characterize an atypical Th2 response in ulcerative colitis. J. Clin. Invest. 2004; 113:1490-1497. [PubMed: 15146247] 
Gadola SD, Silk JD, Jeans A, Illarionov PA, Salio M, Besra GS, Dwek R, Butters TD, Platt FM, Cerundolo V. Impaired selection of invariant natural killer T cells in diverse mouse models of glycosphingolipid lysosomal storage diseases. J. Exp. Med. 2006; 203:2293-2303. [PubMed: 16982810]

Gapin L, Matsuda JL, Surh CD, Kronenberg M. NKT cells derive from double-positive thymocytes that are positively selected by CD1d. Nat. Immunol. 2001; 2:971-978. [PubMed: 11550008]

Garcia-Alles LF, Versluis K, Maveyraud L, Vallina AT, Sansano S, Bello NF, Gober HJ, Guillet V, de la Salle H, Puzo G, et al. Endogenous phosphatidylcholine and a long spacer ligand stabilize the lipid-binding groove of CD1b. EMBO J. 2006; 25:3684-3692. [PubMed: 16874306]

Garcia-Alles LF, Giacometti G, Versluis C, Maveyraud L, de Paepe D, Guiard J, Tranier S, Gilleron M, Prandi J, Hanau D, et al. Crystal structure of human CD1e reveals a groove suited for lipidexchange processes. Proc. Natl. Acad. Sci. USA. 2011; 108:13230-13235. [PubMed: 21788486]

Garzon D, Anselmi C, Bond PJ, Faraldo-Gomez JD. Dynamics of the antigen-binding grooves in CD1 proteins: reversible hydrophobic collapse in the lipid-free state. J. Biol. Chem. 2013; 288:1952819536. [PubMed: 23677998]

Geissmann F, Cameron TO, Sidobre S, Manlongat N, Kronenberg M, Briskin MJ, Dustin ML, Littman DR. Intravascular immune surveillance by $\mathrm{CXCR}^{+} \mathrm{NKT}$ cells patrolling liver sinusoids. PLoS Biol. 2005; 3:e113. [PubMed: 15799695]

Giaccone G, Punt CJ, Ando Y, Ruijter R, Nishi N, Peters M, von Blomberg BM, Scheper RJ, van der Vliet HJ, van den Eertwegh AJ, et al. A phase I study of the natural killer T-cell ligand agalactosylceramide (KRN7000) in patients with solid tumors. Clin. Cancer Res. 2002; 8:37023709. [PubMed: 12473579]

Girardi E, Zajonc DM. Molecular basis of lipid antigen presentation by CD1d and recognition by natural killer T cells. Immunol. Rev. 2012; 250:167-179. [PubMed: 23046129]

Girardi E, Maricic I, Wang J, Mac TT, Iyer P, Kumar V, Zajonc DM. Type II natural killer T cells use features of both innate-like and conventional $\mathrm{T}$ cells to recognize sulfatide self antigens. Nat. Immunol. 2012; 13:851-856. [PubMed: 22820602]

Gogolak P, Rethi B, Szatmari I, Lanyi A, Dezso B, Nagy L, Rajnavolgyi E. Differentiation of CD1aand $\mathrm{CD} 1 \mathrm{a}^{+}$monocyte-derived dendritic cells is biased by lipid environment and PPAR $\gamma$. Blood. 2007; 109:643-652. [PubMed: 16968896]

Grant EP, Degano M, Rosat JP, Stenger S, Modlin RL, Wilson IA, Porcelli SA, Brenner MB. Molecular recognition of lipid antigens by T cell receptors. J. Exp. Med. 1999; 189:195-205. [PubMed: 9874576]

Guebre-Xabier M, Yang S, Lin HZ, Schwenk R, Krzych U, Diehl AM. Altered hepatic lymphocyte subpopulations in obesity-related murine fatty livers: potential mechanism for sensitization to liver damage. Hepatology. 2000; 31:633-640. [PubMed: 10706553]

Hage CA, Kohli LL, Cho S, Brutkiewicz RR, Twigg HL 3rd, Knox KS. Human immunodeficiency virus gp120 downregulates CD1d cell surface expression. Immunol. Lett. 2005; 98:131-135. [PubMed: 15790518]

Haig NA, Guan Z, Li D, McMichael A, Raetz CR, Xu XN. Identification of self-lipids presented by CD1c and CD1d proteins. J. Biol. Chem. 2011; 286:37692-37701. [PubMed: 21900247]

Halder RC, Aguilera C, Maricic I, Kumar V. Type II NKT cell-mediated anergy induction in type I NKT cells prevents inflammatory liver disease. J. Clin. Invest. 2007; 117:2302-2312. [PubMed: 17641782]

Hegde S, Chen X, Keaton JM, Reddington F, Besra GS, Gumperz JE. NKT cells direct monocytes into a DC differentiation pathway. J. Leukoc. Biol. 2007; 81:1224-1235. [PubMed: 17311932]

Heller F, Fuss IJ, Nieuwenhuis EE, Blumberg RS, Strober W. Oxazolone colitis, a Th2 colitis model resembling ulcerative colitis, is mediated by IL-13-producing NK-T cells. Immunity. 2002; 17:629-638. [PubMed: 12433369]

Heller F, Florian P, Bojarski C, Richter J, Christ M, Hillenbrand B, Mankertz J, Gitter AH, Burgel N, Fromm M, et al. Interleukin-13 is the key effector Th2 cytokine in ulcerative colitis that affects epithelial tight junctions, apoptosis, and cell restitution. Gastroenterology. 2005; 129:550-564. [PubMed: 16083712] 
Hermans IF, Silk JD, Gileadi U, Salio M, Mathew B, Ritter G, Schmidt R, Harris AL, Old L, Cerundolo V. NKT cells enhance $\mathrm{CD}^{+}$and $\mathrm{CD} 8^{+} \mathrm{T}$ cell responses to soluble antigen in vivo through direct interaction with dendritic cells. J. Immunol. 2003; 171:5140-5147. [PubMed: 14607913]

Hermans IF, Silk JD, Gileadi U, Masri SH, Shepherd D, Farrand KJ, Salio M, Cerundolo V. Dendritic cell function can be modulated through cooperative actions of TLR ligands and invariant NKT cells. J. Immunol. 2007; 178:2721-2729. [PubMed: 17312114]

Honey K, Benlagha K, Beers C, Forbush K, Teyton L, Kleijmeer MJ, Rudensky AY, Bendelac A. Thymocyte expression of cathepsin L is essential for NKT cell development. Nat. Immunol. 2002; 3:1069-1074. [PubMed: 12368909]

Huang S, Cheng TY, Young DC, Layre E, Madigan CA, Shires J, Cerundolo V, Altman JD, Moody DB. Discovery of deoxyceramides and diacylglycerols as CD1b scaffold lipids among diverse groove-blocking lipids of the human CD1 system. Proc. Natl. Acad. Sci. USA. 2011; 108:1933519340. [PubMed: 22087000]

Ishikawa A, Motohashi S, Ishikawa E, Fuchida H, Higashino K, Otsuji M, Iizasa T, Nakayama T, Taniguchi M, Fujisawa T. A phase I study of alpha-galactosylceramide (KRN7000)-pulsed dendritic cells in patients with advanced and recurrent non-small cell lung cancer. Clin. Cancer Res. 2005; 11:1910-1917. [PubMed: 15756017]

Izhak L, Ambrosino E, Kato S, Parish ST, O’Konek JJ, Weber H, Xia Z, Venzon D, Berzofsky JA, Terabe M. Delicate balance among three types of $\mathrm{T}$ cells in concurrent regulation of tumor immunity. Cancer Res. 2013; 73:1514-1523. [PubMed: 23319803]

Jahng A, Maricic I, Aguilera C, Cardell S, Halder RC, Kumar V. Prevention of autoimmunity by targeting a distinct, noninvariant CD1d-reactive T cell population reactive to sulfatide. J. Exp. Med. 2004; 199:947-957. [PubMed: 15051763]

Jayawardena-Wolf J, Benlagha K, Chiu YH, Mehr R, Bendelac A. CD1d endosomal trafficking is independently regulated by an intrinsic CD1d-encoded tyrosine motif and by the invariant chain. Immunity. 2001; 15:897-908. [PubMed: 11754812]

Ji Y, Sun S, Xu A, Bhargava P, Yang L, Lam KS, Gao B, Lee CH, Kersten S, Qi L. Activation of natural killer T cells promotes M2 Macrophage polarization in adipose tissue and improves systemic glucose tolerance via interleukin-4 (IL-4)/STAT6 protein signaling axis in obesity. J. Biol. Chem. 2012; 287:13561-13571. [PubMed: 22396530]

Jostins L, Ripke S, Weersma RK, Duerr RH, McGovern DP, Hui KY, Lee JC, Schumm LP, Sharma Y, Anderson CA, et al. Host-microbe interactions have shaped the genetic architecture of inflammatory bowel disease. Nature. 2012; 491:119-124. [PubMed: 23128233]

Kang SJ, Cresswell P. Calnexin, calreticulin, and ERp57 cooperate in disulfide bond formation in human CD1d heavy chain. J. Biol. Chem. 2002; 277:44838-44844. [PubMed: 12239218]

Kang SJ, Cresswell P. Saposins facilitate CD1d-restricted presentation of an exogenous lipid antigen to T cells. Nat. Immunol. 2004; 5:175-181. [PubMed: 14716312]

Karner M, Kocjan A, Stein J, von Boyen G, Uebel P, Schmidt C, Kupcinskas L, Dina I, Hanemann A, Zuelch F, et al. Modified release phosphatidylcholine LT-02 in active ulcerative colitis - a randomized, placebo-controlled multicentre study. Gastroenterology. 2012; 142:S-211.

Kaser A, Hava DL, Dougan SK, Chen Z, Zeissig S, Brenner MB, Blumberg RS. Microsomal triglyceride transfer protein regulates endogenous and exogenous antigen presentation by group 1 CD1 molecules. Eur. J. Immunol. 2008; 38:2351-2359. [PubMed: 18624350]

Kasmar A, Van Rhijn I, Moody DB. The evolved functions of CD1 during infection. Curr. Opin Immunol. 2009; 21:397-403. [PubMed: 19541469]

Kasmar AG, van Rhijn I, Cheng TY, Turner M, Seshadri C, Schiefner A, Kalathur RC, Annand JW, de Jong A, Shires J, et al. CD1b tetramers bind $\alpha \beta$ T cell receptors to identify a mycobacterial glycolipid-reactive T cell repertoire in humans. J. Exp. Med. 2011; 208:1741-1747. [PubMed: 21807869]

Kawano T, Cui J, Koezuka Y, Toura I, Kaneko Y, Motoki K, Ueno H, Nakagawa R, Sato H, Kondo E, et al. CD1d-restricted and TCR-mediated activation of va14 NKT cells by glycosylceramides. Science. 1997; 278:1626-1629. [PubMed: 9374463] 
Kawana K, Quayle AJ, Ficarra M, Ibana JA, Shen L, Kawana Y, Yang H, Marrero L, Yavagal S, Greene SJ, et al. CD1d degradation in Chlamydia trachomatis-infected epithelial cells is the result of both cellular and chlamydial proteasomal activity. J. Biol. Chem. 2007; 282:7368-7375. [PubMed: 17215251]

Kinjo Y, Kronenberg M. Detection of microbes by natural killer T cells. Adv. Exp. Med. Biol. 2009; 633:17-26. [PubMed: 19209678]

Kinjo Y, Wu D, Kim G, Xing GW, Poles MA, Ho DD, Tsuji M, Kawahara K, Wong CH, Kronenberg M. Recognition of bacterial glycosphingolipids by natural killer T cells. Nature. 2005; 434:520525. [PubMed: 15791257]

Kinjo Y, Tupin E, Wu D, Fujio M, Garcia-Navarro R, Benhnia MR, Zajonc DM, Ben-Menachem G, Ainge GD, Painter GF, et al. Natural killer T cells recognize diacylglycerol antigens from pathogenic bacteria. Nat. Immunol. 2006; 7:978-986. [PubMed: 16921381]

Kinjo Y, Illarionov P, Vela JL, Pei B, Girardi E, Li X, Li Y, Imamura M, Kaneko Y, Okawara A, et al. Invariant natural killer T cells recognize glycolipids from pathogenic Gram-positive bacteria. Nat. Immunol. 2011; 12:966-974. [PubMed: 21892173]

Kitamura H, Iwakabe K, Yahata T, Nishimura S, Ohta A, Ohmi Y, Sato M, Takeda K, Okumura K, Van Kaer L, et al. The natural killer T NKT cell ligand a-galactosylceramide demonstrates its immunopotentiating effect by inducing interleukin (IL)-12 production by dendritic cells and IL-12 receptor expression on NKT cells. J. Exp. Med. 1999; 189:1121-1128. [PubMed: 10190903]

Kobayashi E, Motoki K, Uchida T, Fukushima H, Koezuka Y. KRN7000, a novel immunomodulator, and its antitumor activities. Oncol. Res. 1995; 7:529-534. [PubMed: 8866665]

Koh YI, Kim HY, Meyer EH, Pichavant M, Akbari O, Yasumi T, Savage PB, Dekruyff RH, Umetsu DT. Activation of nonclassical CD1d-restricted NK T cells induces airway hyperreactivity in $\beta 2$ microglobulin-deficient mice. J. Immunol. 2008; 181:4560-4569. [PubMed: 18802058]

Kolter T, Sandhoff K. Lysosomal degradation of membrane lipids. FEBS Lett. 2010; 584:1700-1712. [PubMed: 19836391]

Kotas ME, Lee HY, Gillum MP, Annicelli C, Guigni BA, Shulman GI, Medzhitov R. Impact of CD1d deficiency on metabolism. PLoS One. 2011; 6:e25478. [PubMed: 21980475]

Leslie DS, Dascher CC, Cembrola K, Townes MA, Hava DL, Hugendubler LC, Mueller E, Fox L, Roura-Mir C, Moody DB, et al. Serum lipids regulate dendritic cell CD1 expression and function. Immunology. 2008; 125:289-301. [PubMed: 18445008]

Liao CM, Zimmer MI, Shanmuganad S, Yu HT, Cardell SL, Wang CR. dysregulation of CD1drestricted type II natural killer T cells leads to spontaneous development of colitis in mice. Gastroenterology. 2012; 142:326-334. e1-e2. [PubMed: 22057113]

Lin Y, Roberts TJ, Spence PM, Brutkiewicz RR. Reduction in CD1d expression on dendritic cells and macrophages by an acute virus infection. J. Leukoc. Biol. 2005; 77:151-158. [PubMed: 15548574]

Lopez-Sagaseta J, Sibener LV, Kung JE, Gumperz J, Adams EJ. Lysophospholipid presentation by CD1d and recognition by a human natural killer T-cell receptor. EMBO J. 2012; 31:2047-2059. [PubMed: 22395072]

Lotter H, Gonzalez-Roldan N, Lindner B, Winau F, Isibasi A, Moreno-Lafont M, Ulmer AJ, Holst O, Tannich E, Jacobs T. Natural killer T cells activated by a lipopeptidophosphoglycan from Entamoeba histolytica are critically important to control amebic liver abscess. PLoS Pathog. 2009; 5:e1000434. [PubMed: 19436711]

Ly D, Kasmar AG, Cheng TY, de Jong A, Huang S, Roy S, Bhatt A, van Summeren RP, Altman JD, Jacobs WR Jr, et al. CD1c tetramers detect ex vivo T cell responses to processed phosphomycoketide antigens. J. Exp. Med. 2013; 210:729-741. [PubMed: 23530121]

Lynch L, O'Shea D, Winter DC, Geoghegan J, Doherty DG, O'Farrelly C. Invariant NKT cells and CD1d ${ }^{+}$cells amass in human omentum and are depleted in patients with cancer and obesity. Eur. J. Immunol. 2009; 39:1893-1901. [PubMed: 19585513]

Lynch L, Nowak M, Varghese B, Clark J, Hogan AE, Toxavidis V, Balk SP, O'Shea D, O'Farrelly C, Exley MA. Adipose tissue invariant NKT cells protect against diet-induced obesity and metabolic disorder through regulatory cytokine production. Immunity. 2012; 37:574-587. [PubMed: 22981538] 
Mantell BS, Stefanovic-Racic M, Yang X, Dedousis N, Sipula IJ, O’Doherty RM. Mice lacking NKT cells but with a complete complement of $\mathrm{CD}^{+} \mathrm{T}$-cells are not protected against the metabolic abnormalities of diet-induced obesity. PLoS One. 2011; 6:e19831. [PubMed: 21674035]

Matsuda JL, Naidenko OV, Gapin L, Nakayama T, Taniguchi M, Wang CR, Koezuka Y, Kronenberg M. Tracking the response of natural killer T cells to a glycolipid antigen using CD1d tetramers. J. Exp. Med. 2000; 192:741-754. [PubMed: 10974039]

Mattner J, Debord KL, Ismail N, Goff RD, Cantu C 3rd, Zhou D, Saint-Mezard P, Wang V, Gao Y, Yin N, et al. Exogenous and endogenous glycolipid antigens activate NKT cells during microbial infections. Nature. 2005; 434:525-529. [PubMed: 15791258]

Metelitsa LS, Wu HW, Wang H, Yang Y, Warsi Z, Asgharzadeh S, Groshen S, Wilson SB, Seeger RC. Natural killer T cells infiltrate neuroblastomas expressing the chemokine CCL2. J. Exp. Med. 2004; 199:1213-1221. [PubMed: 15123743]

Moll M, Kuylenstierna C, Gonzalez VD, Andersson SK, Bosnjak L, Sonnerborg A, Quigley MF, Sandberg JK. Severe functional impairment and elevated PD-1 expression in CD1d-restricted NKT cells retained during chronic HIV-1 infection. Eur. J. Immunol. 2009; 39:902-911. [PubMed: 19197939]

Molling JW, Langius JA, Langendijk JA, Leemans CR, Bontkes HJ, van der Vliet HJ, von Blomberg BM, Scheper RJ, van den Eertwegh AJ. Low levels of circulating invariant natural killer T cells predict poor clinical outcome in patients with head and neck squamous cell carcinoma. J. Clin. Oncol. 2007; 25:862-868. [PubMed: 17327607]

Montoya CJ, Jie HB, Al-Harthi L, Mulder C, Patino PJ, Rugeles MT, Krieg AM, Landay AL, Wilson SB. Activation of plasmacytoid dendritic cells with TLR9 agonists initiates invariant NKT cellmediated cross-talk with myeloid dendritic cells. J. Immunol. 2006; 177:1028-1039. [PubMed: 16818759]

Moody DB, Briken V, Cheng TY, Roura-Mir C, Guy MR, Geho DH, Tykocinski ML, Besra GS, Porcelli SA. Lipid length controls antigen entry into endosomal and nonendosomal pathways for CD1b presentation. Nat. Immunol. 2002; 3:435-442. [PubMed: 11938350]

Moody DB, Young DC, Cheng TY, Rosat JP, Roura-Mir C, O'Connor PB, Zajonc DM, Walz A, Miller MJ, Levery SB, et al. T cell activation by lipopeptide antigens. Science. 2004; 303:527531. [PubMed: 14739458]

Moody DB, Zajonc DM, Wilson IA. Anatomy of CD1-lipid antigen complexes. Nat. Rev. Immunol. 2005; 5:387-399. [PubMed: 15864273]

Motohashi S, Ishikawa A, Ishikawa E, Otsuji M, Iizasa T, Hanaoka H, Shimizu N, Horiguchi S, Okamoto Y, Fujii S, et al. A phase I study of in vitro expanded natural killer T cells in patients with advanced and recurrent non-small cell lung cancer. Clin. Cancer Res. 2006; 12:6079-6086. [PubMed: 17028247]

Motohashi S, Nagato K, Kunii N, Yamamoto H, Yamasaki K, Okita K, Hanaoka H, Shimizu N, Suzuki M, Yoshino I, et al. A phase I-II study of alpha-galactosylceramide-pulsed IL-2/GMCSF-cultured peripheral blood mononuclear cells in patients with advanced and recurrent nonsmall cell lung cancer. J. Immunol. 2009; 182:2492-2501. [PubMed: 19201905]

Motoki K, Maeda K, Ueno H, Kobayashi E, Uchida T, Fukushima H, Koezuka Y. Antitumor activities of combined treatment with a novel immunomodulator, $(2 S, 3 S, 4 R)-1-O$-(a-dgalactopyranosyl)-2-( $N$-hexacosanoyl-amino)-1,3,4-octadecanetriol (KRN7000), and radiotherapy in tumor-bearing mice. Oncol. Res. 1996; 8:155-162. [PubMed: 8869965]

Muindi K, Cernadas M, Watts GF, Royle L, Neville DC, Dwek RA, Besra GS, Rudd PM, Butters TD, Brenner MB. Activation state and intracellular trafficking contribute to the repertoire of endogenous glycosphingolipids presented by CD1d [corrected]. Proc. Natl. Acad. Sci. USA. 2010; 107:3052-3057. [PubMed: 20133624]

Nagarajan NA, Kronenberg M. Invariant NKT cells amplify the innate immune response to lipopolysaccharide. J. Immunol. 2007; 178:2706-2713. [PubMed: 17312112]

Nagato K, Motohashi S, Ishibashi F, Okita K, Yamasaki K, Moriya Y, Hoshino H, Yoshida S, Hanaoka H, Fujii S, et al. Accumulation of activated invariant natural killer T cells in the tumor microenvironment after a-galactosylceramide-pulsed antigen presenting cells. J. Clin. Immunol. 2012; 32:1071-1081. [PubMed: 22534863] 
Odyniec AN, Barral DC, Garg S, Tatituri RV, Besra GS, Brenner MB. Regulation of CD1 antigenpresenting complex stability. J. Biol. Chem. 2010; 285:11937-11947. [PubMed: 20133943]

O'Konek JJ, Illarionov P, Khursigara DS, Ambrosino E, Izhak L, Castillo BF 2nd, Raju R, Khalili M, Kim HY, Howell AR, et al. Mouse and human iNKT cell agonist $\beta$-mannosylceramide reveals a distinct mechanism of tumor immunity. J. Clin. Invest. 2011; 121:683-694. [PubMed: 21245578]

Olszak T, An D, Zeissig S, Vera MP, Richter J, Franke A, Glickman JN, Siebert R, Baron RM, Kasper DL, et al. Microbial exposure during early life has persistent effects on natural killer T cell function. Science. 2012; 336:489-493. [PubMed: 22442383]

Orange JS. Human natural killer cell deficiencies and susceptibility to infection. Microbes Infect. 2002; 4:1545-1558. [PubMed: 12505527]

Paduraru C, Bezbradica JS, Kunte A, Kelly R, Shayman JA, Veerapen N, Cox LR, Besra GS, Cresswell P. Role for lysosomal phospholipase A2 in iNKT cell-mediated CD1d recognition. Proc. Natl. Acad. Sci. USA. 2013; 110:5097-5102. [PubMed: 23493550]

Paget C, Mallevaey T, Speak AO, Torres D, Fontaine J, Sheehan KC, Capron M, Ryffel B, Faveeuw C, Leite de Moraes M, et al. Activation of invariant NKT cells by toll-like receptor 9-stimulated dendritic cells requires type I interferon and charged glycosphingolipids. Immunity. 2007; 27:597-609. [PubMed: 17950005]

Park SH, Roark JH, Bendelac A. Tissue-specific recognition of mouse CD1 molecules. J. Immunol. 1998; 160:3128-3134. [PubMed: 9531267]

Park SH, Weiss A, Benlagha K, Kyin T, Teyton L, Bendelac A. The mouse CD1d-restricted repertoire is dominated by a few autoreactive T cell receptor families. J. Exp. Med. 2001; 193:893-904. [PubMed: 11304550]

Park JJ, Kang SJ, De Silva AD, Stanic AK, Casorati G, Hachey DL, Cresswell P, Joyce S. Lipidprotein interactions: biosynthetic assembly of CD1 with lipids in the endoplasmic reticulum is evolutionarily conserved. Proc. Natl. Acad. Sci. USA. 2004; 101:1022-1026. [PubMed: 14722359]

Patel O, Pellicci DG, Gras S, Sandoval-Romero ML, Uldrich AP, Mallevaey T, Clarke AJ, Le Nours J, Theodossis A, Cardell SL, et al. Recognition of CD1d-sulfatide mediated by a type II natural killer T cell antigen receptor. Nat. Immunol. 2012; 13:857-863. [PubMed: 22820603]

Pei B, Speak AO, Shepherd D, Butters T, Cerundolo V, Platt FM, Kronenberg M. Diverse endogenous antigens for mouse NKT cells: self-antigens that are not glycosphingolipids. J. Immunol. 2011; 186:1348-1360. [PubMed: 21191069]

Pellicci DG, Clarke AJ, Patel O, Mallevaey T, Beddoe T, Le Nours J, Uldrich AP, McCluskey J, Besra GS, Porcelli SA, et al. Recognition of $\beta$-linked self glycolipids mediated by natural killer T cell antigen receptors. Nat. Immunol. 2011; 12:827-833. [PubMed: 21804559]

Planell N, Lozano JJ, Mora-Buch R, Masamunt MC, Jimeno M, Ordás I, Esteller M, Ricart E, Piqué JM, Panés J, et al. Transcriptional analysis of the intestinal mucosa of patients with ulcerative colitis in remission reveals lasting epithelial cell alterations. Gut. 2013; 62:967-976. [PubMed: 23135761]

Porcelli S, Brenner MB, Greenstein JL, Balk SP, Terhorst C, Bleicher PA. Recognition of cluster of differentiation 1 antigens by human CD4-CD8-cytolytic T lymphocytes. Nature. 1989; 341:447450. [PubMed: 2477705]

Porcelli S, Morita CT, Brenner MB. CD1b restricts the response of human CD4-8-T lymphocytes to a microbial antigen. Nature. 1992; 360:593-597. [PubMed: 1281285]

Prigozy TI, Naidenko O, Qasba P, Elewaut D, Brossay L, Khurana A, Natori T, Koezuka Y, Kulkarni A, Kronenberg M. Glycolipid antigen processing for presentation by CD1d molecules. Science. 2001; 291:664-667. [PubMed: 11158680]

Raftery MJ, Winau F, Kaufmann SH, Schaible UE, Schonrich G. CD1 antigen presentation by human dendritic cells as a target for herpes simplex virus immune evasion. J. Immunol. 2006; 177:62076214. [PubMed: 17056550]

Raftery MJ, Winau F, Giese T, Kaufmann SH, Schaible UE, Schonrich G. Viral danger signals control CD1d de novo synthesis and NKT cell activation. Eur. J. Immunol. 2008; 38:668-679. [PubMed: 18253929] 
Raghuraman G, Geng Y, Wang CR. IFN-beta-mediated up-regulation of CD1d in bacteria-infected APCs. J. Immunol. 2006; 177:7841-7848. [PubMed: 17114455]

Relloso M, Cheng TY, Im JS, Parisini E, Roura-Mir C, DeBono C, Zajonc DM, Murga LF, Ondrechen MJ, Wilson IA, et al. pH-dependent interdomain tethers of $\mathrm{CD} 1 \mathrm{~b}$ regulate its antigen capture. Immunity. 2008; 28:774-786. [PubMed: 18538591]

Renukaradhya GJ, Webb TJ, Khan MA, Lin YL, Du W, Gervay-Hague J, Brutkiewicz RR. Virusinduced inhibition of CD1d1-mediated antigen presentation: reciprocal regulation by $\mathrm{p} 38$ and ERK. J. Immunol. 2005; 175:4301-4308. [PubMed: 16177070]

Renukaradhya GJ, Khan MA, Shaji D, Brutkiewicz RR. Vesicular stomatitis virus matrix protein impairs CD1d-mediated antigen presentation through activation of the p38 MAPK pathway. J. Virol. 2008; 82:12535-12542. [PubMed: 18815300]

Rhost S, Lofbom L, Rynmark BM, Pei B, Mansson JE, Teneberg S, Blomqvist M, Cardell SL. Identification of novel glycolipid ligands activating a sulfatide-reactive, CD1d-restricted, type II natural killer T lymphocyte. Eur. J. Immunol. 2012; 42:2851-2860. [PubMed: 22777932]

Richter J, Neparidze N, Zhang L, Nair S, Monesmith T, Sundaram R, Miesowicz F, Dhodapkar KM, Dhodapkar MV. Clinical regressions and broad immune activation following combination therapy targeting human NKT cells in myeloma. Blood. 2013; 121:423-430. [PubMed: 23100308]

Rossjohn J, Pellicci DG, Patel O, Gapin L, Godfrey DI. Recognition of CD1d-restricted antigens by natural killer T cells. Nat. Rev. Immunol. 2012; 12:845-857. [PubMed: 23154222]

Roy KC, Maricic I, Khurana A, Smith TR, Halder RC, Kumar V. Involvement of secretory and endosomal compartments in presentation of an exogenous self-glycolipid to type II NKT cells. J. Immunol. 2008; 180:2942-2950. [PubMed: 18292516]

Salio M, Speak AO, Shepherd D, Polzella P, Illarionov PA, Veerapen N, Besra GS, Platt FM, Cerundolo V. Modulation of human natural killer T cell ligands on TLR-mediated antigenpresenting cell activation. Proc. Natl. Acad. Sci. USA. 2007; 104:20490-20495. [PubMed: 18077358]

Sanchez DJ, Gumperz JE, Ganem D. Regulation of CD1d expression and function by a herpesvirus infection. J. Clin. Invest. 2005; 115:1369-1378. [PubMed: 15864354]

Santos CR, Schulze A. Lipid metabolism in cancer. FEBS J. 2012; 279:2610-2623. [PubMed: 22621751]

Saubermann LJ, Beck P, De Jong YP, Pitman RS, Ryan MS, Kim HS, Exley M, Snapper S, Balk SP, Hagen SJ, et al. Activation of natural killer T cells by a-galactosylceramide in the presence of CD1d provides protection against colitis in mice. Gastroenterology. 2000; 119:119-128. [PubMed: 10889161]

Scharf L, Li NS, Hawk AJ, Garzon D, Zhang T, Fox LM, Kazen AR, Shah S, Haddadian EJ, Gumperz JE, et al. The $2.5 \AA$ structure of CD1c in complex with a mycobacterial lipid reveals an open groove ideally suited for diverse antigen presentation. Immunity. 2010; 33:853-862. [PubMed: 21167756]

Schiechl G, Bauer B, Fuss I, Lang SA, Moser C, Ruemmele P, Rose-John S, Neurath MF, Geissler EK, Schlitt HJ, et al. Tumor development in murine ulcerative colitis depends on MyD88 signaling of colonic F4/80 ${ }^{+} \mathrm{CD} 11 \mathrm{~b}^{\text {high }} \mathrm{Gr} 1^{\text {low }}$ macrophages. J. Clin. Invest. 2011; 121:16921708. [PubMed: 21519141]

Schipper HS, Rakhshandehroo M, van de Graaf SF, Venken K, Koppen A, Stienstra R, Prop S, Meerding J, Hamers N, Besra G, et al. Natural killer T cells in adipose tissue prevent insulin resistance. J. Clin. Invest. 2012; 122:3343-3354. [PubMed: 22863618]

Seok J, Warren HS, Cuenca AG, Mindrinos MN, Baker HV, Xu W, Richards DR, McDonald-Smith GP, Gao H, Hennessy L, et al. Genomic responses in mouse models poorly mimic human inflammatory diseases. Proc. Natl. Acad. Sci. USA. 2013; 110:3507-3512. [PubMed: 23401516]

Seshadri C, Shenoy M, Wells RD, Hensley-McBain T, Andersen-Nissen E, McElrath MJ, Cheng TY, Moody DB, Hawn TR. Human CD1a deficiency is common and genetically regulated. J. Immunol. 2013; 191:1586-1593. [PubMed: 23858036] 
Shamshiev A, Gober HJ, Donda A, Mazorra Z, Mori L, De Libero G. Presentation of the same glycolipid by different CD1 molecules. J. Exp. Med. 2002; 195:1013-1021. [PubMed: 11956292]

Shinya E, Owaki A, Shimizu M, Takeuchi J, Kawashima T, Hidaka C, Satomi M, Watari E, Sugita M, Takahashi H. Endogenously expressed HIV-1 nef down-regulates antigen-presenting molecules, not only class I MHC but also CD1a, in immature dendritic cells. Virology. 2004; 326:79-89. [PubMed: 15262497]

Shiratsuchi T, Schneck J, Kawamura A, Tsuji M. Human CD1 dimeric proteins as indispensable tools for research on CD1-binding lipids and CD1-restricted T cells. J. Immunol. Methods. 2009; 345:49-59. [PubMed: 19374905]

Sieling PA, Chatterjee D, Porcelli SA, Prigozy TI, Mazzaccaro RJ, Soriano T, Bloom BR, Brenner MB, Kronenberg M, Brennan PJ, et al. CD1-restricted T cell recognition of microbial lipoglycan antigens. Science. 1995; 269:227-230. [PubMed: 7542404]

Skold M, Xiong X, Illarionov PA, Besra GS, Behar SM. Interplay of cytokines and microbial signals in regulation of CD1d expression and NKT cell activation. J. Immunol. 2005; 175:3584-3593. [PubMed: 16148102]

Smyth MJ, Thia KY, Street SE, Cretney E, Trapani JA, Taniguchi M, Kawano T, Pelikan SB, Crowe NY, Godfrey DI. Differential tumor surveillance by natural killer (NK) and NKT cells. J. Exp. Med. 2000; 191:661-668. [PubMed: 10684858]

Song L, Asgharzadeh S, Salo J, Engell K, Wu HW, Sposto R, Ara T, Silverman AM, DeClerck YA, Seeger RC, et al. Valpha24-invariant NKT cells mediate antitumor activity via killing of tumorassociated macrophages. J. Clin. Invest. 2009; 119:1524-1536. [PubMed: 19411762]

Sriram V, Du W, Gervay-Hague J, Brutkiewicz RR. Cell wall glycosphingolipids of Sphingomonas paucimobilis are CD1d-specific ligands for NKT cells. Eur. J. Immunol. 2005; 35:1692-1701. [PubMed: 15915536]

Subleski JJ, Jiang Q, Weiss JM, Wiltrout RH. The split personality of NKT cells in malignancy, autoimmune and allergic disorders. Immunotherapy. 2011; 3:1167-1184. [PubMed: 21995570]

Sugita M, Jackman RM, van Donselaar E, Behar SM, Rogers RA, Peters PJ, Brenner MB, Porcelli SA. Cytoplasmic tail-dependent localization of CD1b antigen-presenting molecules to MIICs. Science. 1996; 273:349-352. [PubMed: 8662520]

Sugita M, Porcelli SA, Brenner MB. Assembly and retention of CD1b heavy chains in the endoplasmic reticulum. J. Immunol. 1997; 159:2358-2365. [PubMed: 9278326]

Sugita M, Grant EP, van Donselaar E, Hsu VW, Rogers RA, Peters PJ, Brenner MB. Separate pathways for antigen presentation by CD1 molecules. Immunity. 1999; 11:743-752. [PubMed: 10626896]

Sugita M, van Der Wel N, Rogers RA, Peters PJ, Brenner MB. CD1c molecules broadly survey the endocytic system. Proc. Natl. Acad. Sci. USA. 2000; 97:8445-8450. [PubMed: 10890914]

Swann JB, Uldrich AP, van Dommelen S, Sharkey J, Murray WK, Godfrey DI, Smyth MJ. Type I natural killer T cells suppress tumors caused by p53 loss in mice. Blood. 2009; 113:6382-6385. [PubMed: 19234138]

Tachibana T, Onodera H, Tsuruyama T, Mori A, Nagayama S, Hiai H, Imamura M. Increased intratumor Va24-positive natural killer T cells: a prognostic factor for primary colorectal carcinomas. Clin. Cancer Res. 2005; 11:7322-7327. [PubMed: 16243803]

Tahir SM, Cheng O, Shaulov A, Koezuka Y, Bubley GJ, Wilson SB, Balk SP, Exley MA. Loss of IFN- $\gamma$ production by invariant NK T cells in advanced cancer. J. Immunol. 2001; 167:40464050. [PubMed: 11564825]

Tatituri RV, Watts GF, Bhowruth V, Barton N, Rothchild A, Hsu FF, Almeida CF, Cox LR, Eggeling L, Cardell S, et al. Recognition of microbial and mammalian phospholipid antigens by NKT cells with diverse TCRs. Proc. Natl. Acad. Sci. USA. 2013; 110:1827-1832. [PubMed: 23307809]

Terabe M, Matsui S, Noben-Trauth N, Chen H, Watson C, Donaldson DD, Carbone DP, Paul WE, Berzofsky JA. NKT cell-mediated repression of tumor immunosurveillance by IL-13 and the IL-4R-STAT6 pathway. Nat. Immunol. 2000; 1:515-520. [PubMed: 11101874]

Terabe M, Matsui S, Park JM, Mamura M, Noben-Trauth N, Donaldson DD, Chen W, Wahl SM, Ledbetter S, Pratt B, et al. Transforming growth factor $\beta$ production and myeloid cells are an 
effector mechanism through which CD1d-restricted T cells block cytotoxic T lymphocytemediated tumor immunosurveillance: abrogation prevents tumor recurrence. J. Exp. Med. 2003; 198:1741-1752. [PubMed: 14657224]

Tremaroli V, Backhed F. Functional interactions between the gut microbiota and host metabolism. Nature. 2012; 489:242-249. [PubMed: 22972297]

Tupin E, Kinjo Y, Kronenberg M. The unique role of natural killer T cells in the response to microorganisms. Nat. Rev. Microbiol. 2007; 5:405-417. [PubMed: 17487145]

Tyznik AJ, Tupin E, Nagarajan NA, Her MJ, Benedict CA, Kronenberg M. Cutting edge: the mechanism of invariant NKT cell responses to viral danger signals. J. Immunol. 2008; 181:44524456. [PubMed: 18802047]

Uchida T, Horiguchi S, Tanaka Y, Yamamoto H, Kunii N, Motohashi S, Taniguchi M, Nakayama T, Okamoto Y. Phase I study of alpha-galactosylceramidepulsed antigen presenting cells administration to the nasal submucosa in unresectable or recurrent head and neck cancer. Cancer Immunol. Immunother. 2008; 57:337-345. [PubMed: 17690880]

Uldrich AP, Patel O, Cameron G, Pellicci DG, Day EB, Sullivan LC, Kyparissoudis K, Kjer-Nielsen $\mathrm{L}$, Vivian JP, Cao B, et al. A semi-invariant $\mathrm{Va}_{10}{ }^{+} \mathrm{T}$ cell antigen receptor defines a population of natural killer T cells with distinct glycolipid antigen-recognition properties. Nat. Immunol. 2011; 12:616-623. [PubMed: 21666690]

Van Rhijn I, Kasmar A, de Jong A, Gras S, Bhati M, Doorenspleet ME, de Vries N, Godfrey DI, Altman JD, de Jager W, et al. A conserved human T cell population targets mycobacterial antigens presented by CD1b. Nat. Immunol. 2013; 14:706-713. [PubMed: 23727893]

Vincent MS, Xiong X, Grant EP, Peng W, Brenner MB. CD1a-, b-, and c-restricted TCRs recognize both self and foreign antigens. J. Immunol. 2005; 175:6344-6351. [PubMed: 16272286]

Vivier E, Ugolini S, Blaise D, Chabannon C, Brossay L. Targeting natural killer cells and natural killer T cells in cancer. Nat. Rev. Immunol. 2012; 12:239-252. [PubMed: 22437937]

von Bernuth H, Picard C, Jin Z, Pankla R, Xiao H, Ku CL, Chrabieh M, Mustapha IB, Ghandil P, Camcioglu Y, et al. Pyogenic bacterial infections in humans with MyD88 deficiency. Science. 2008; 321:691-696. [PubMed: 18669862]

Wetterau JR, Aggerbeck LP, Bouma ME, Eisenberg C, Munck A, Hermier M, Schmitz J, Gay G, Rader DJ, Gregg RE. Absence of microsomal triglyceride transfer protein in individuals with abetalipoproteinemia. Science. 1992; 258:999-1001. [PubMed: 1439810]

Winau F, Schwierzeck V, Hurwitz R, Remmel N, Sieling PA, Modlin RL, Porcelli SA, Brinkmann V, Sugita M, Sandhoff K, et al. Saposin C is required for lipid presentation by human CD1b. Nat. Immunol. 2004; 5:169-174. [PubMed: 14716313]

Wingender G, Stepniak D, Krebs P, Lin L, McBride S, Wei B, Braun J, Mazmanian SK, Kronenberg $\mathrm{M}$. Intestinal microbes affect phenotypes and functions of invariant natural killer T cells in mice. Gastroenterology. 2012; 143:418-428. [PubMed: 22522092]

Wong CH, Jenne CN, Lee WY, Leger C, Kubes P. Functional innervation of hepatic iNKT cells is immunosuppressive following stroke. Science. 2011; 334:101-105. [PubMed: 21921158]

Wu L, Parekh VV, Gabriel CL, Bracy DP, Marks-Shulman PA, Tamboli RA, Kim S, MendezFernandez YV, Besra GS, Lomenick JP, et al. Activation of invariant natural killer T cells by lipid excess promotes tissue inflammation, insulin resistance, and hepatic steatosis in obese mice. Proc. Natl. Acad. Sci. USA. 2012; 109:E1143-E1152. [PubMed: 22493234]

Yanagisawa K, Seino K, Ishikawa Y, Nozue M, Todoroki T, Fukao K. Impaired proliferative response of Va24 NKT cells from cancer patients against a-galactosylceramide. J. Immunol. 2002; 168:6494-6499. [PubMed: 12055270]

Yang L, Jhaveri R, Huang J, Qi Y, Diehl AM. Endoplasmic reticulum stress, hepatocyte CD1d and NKT cell abnormalities in murine fatty livers. Lab. Invest. 2007; 87:927-937. [PubMed: 17607300]

Yoshioka K, Ueno Y, Tanaka S, Nagai K, Onitake T, Hanaoka R, Watanabe H, Chayama K. Role of natural killer T cells in the mouse colitis-associated colon cancer model. Scand. J. Immunol. 2012; 75:16-26. [PubMed: 21815907] 
Yu ED, Girardi E, Wang J, Zajonc DM. Cutting edge: structural basis for the recognition of $\beta$-linked glycolipid antigens by invariant NKT cells. J. Immunol. 2011; 187:2079-2083. [PubMed: 21810611]

Yuan W, Dasgupta A, Cresswell P. Herpes simplex virus evades natural killer T cell recognition by suppressing CD1d recycling. Nat. Immunol. 2006; 7:835-842. [PubMed: 16845396]

Yuan W, Qi X, Tsang P, Kang SJ, Illarionov PA, Besra GS, Gumperz J, Cresswell P. Saposin B is the dominant saposin that facilitates lipid binding to human CD1d molecules. Proc. Natl. Acad. Sci. USA. 2007; 104:5551-5556. [PubMed: 17372201]

Yuan W, Kang SJ, Evans JE, Cresswell P. Natural lipid ligands associated with human CD1d targeted to different subcellular compartments. J. Immunol. 2009; 182:4784-4791. [PubMed: 19342656]

Zajonc DM, Crispin MD, Bowden TA, Young DC, Cheng TY, Hu J, Costello CE, Rudd PM, Dwek RA, Miller MJ, et al. Molecular mechanism of lipopeptide presentation by CD1a. Immunity. 2005; 22:209-219. [PubMed: 15723809]

Zeissig S, Blumberg RS. Primary immunodeficiency associated with defects in CD1 and CD1restricted T cells. Ann. NY Acad Sci. 2012; 1250:14-24. [PubMed: 22276638]

Zeissig S, Kaser A, Dougan SK, Nieuwenhuis EE, Blumberg RS. Role of NKT cells in the digestive system. III. Role of NKT cells in intestinal immunity. Am. J. Physiol. Gastrointest. Liver Physiol. 2007; 293:G1101-G1105. [PubMed: 17717040]

Zeissig S, Dougan SK, Barral DC, Junker Y, Chen Z, Kaser A, Ho M, Mandel H, McIntyre A, Kennedy SM, et al. Primary deficiency of microsomal triglyceride transfer protein in human abetalipoproteinemia is associated with loss of CD1 function. J. Clin. Invest. 2010; 120:28892899. [PubMed: 20592474]

Zeissig S, Murata K, Sweet L, Publicover J, Hu Z, Kaser A, Bosse E, Iqbal J, Hussain MM, Balschun $\mathrm{K}$, et al. Hepatitis B virus-induced lipid alterations contribute to natural killer T cell-dependent protective immunity. Nat. Med. 2012; 18:1060-1068. [PubMed: 22706385]

Zhang SY, Jouanguy E, Ugolini S, Smahi A, Elain G, Romero P, Segal D, Sancho-Shimizu V, Lorenzo L, Puel A, et al. TLR3 deficiency in patients with herpes simplex encephalitis. Science. 2007; 317:1522-1527. [PubMed: 17872438]

Zhou D, Cantu C 3rd, Sagiv Y, Schrantz N, Kulkarni AB, Qi X, Mahuran DJ, Morales CR, Grabowski GA, Benlagha K, et al. Editing of CD1d-bound lipid antigens by endosomal lipid transfer proteins. Science. 2004a; 303:523-527. [PubMed: 14684827]

Zhou D, Mattner J, Cantu C 3rd, Schrantz N, Yin N, Gao Y, Sagiv Y, Hudspeth K, Wu YP, Yamashita T, et al. Lysosomal glycosphingolipid recognition by NKT cells. Science. 2004b; 306:17861789. [PubMed: 15539565]

Zimmer MI, Nguyen HP, Wang B, Xu H, Colmone A, Felio K, Choi HJ, Zhou P, Alegre ML, Wang CR. Polymorphisms in CD1d affect antigen presentation and the activation of CD1d-restricted T cells. Proc. Natl. Acad. Sci. USA. 2009; 106:1909-1914. [PubMed: 19179286]

\section{Biographies}

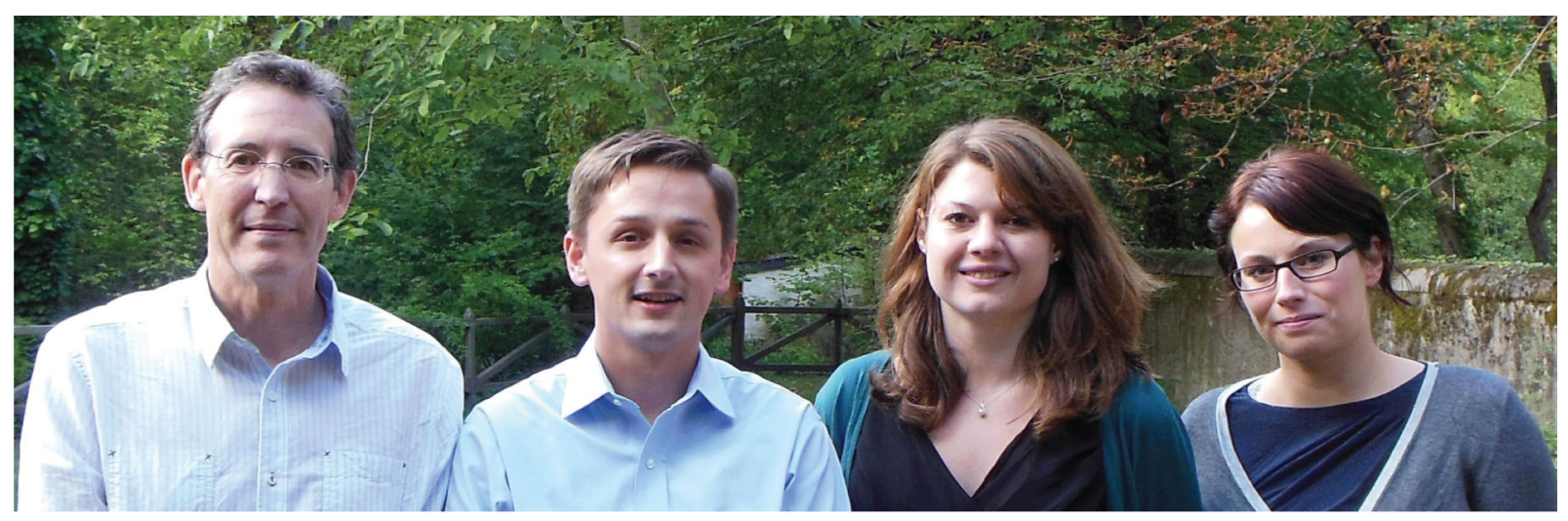


C. Marie Dowds studied Biosciences at the University of Kaiserslautern, Germany. After completion of her master's degree in the group of Dr. Stefan Kins, she joined the laboratory of Dr. Zeissig at the Department of Internal Medicine, Kiel University (Kiel, Germany) as $\mathrm{PhD}$ student. In her PhD studies, Dowds investigates the role of NKT cells and lipid antigens in intestinal inflammation.

Sabin-Christin Kornell studied Biology at the Christian-Albrechts-University of Kiel and received her master's degree in cell biology and physiology in 2013. In May 2013, Kornell started her PhD studies in Dr. Zeissig's group at the Department of Internal Medicine, Kiel University, Germany (Kiel, Germany).

Richard S. Blumberg, MD, is Professor of Medicine at Harvard Medical School, Chief of the Division of Gastroenterology, Hepatology and Endoscopy at Brigham and Women's Hospital, co-Director of the Biomedical Research Institute at Brigham and Women's Hospital and co-Director of the Harvard Digestive Diseases Center. He received his medical degree from Jefferson Medical College (Philadelphia, PA), internship and residency at The New York Hospital, Cornell Medical Center followed by fellowship training in infectious diseases at Massachusetts General Hospital, gastroenterology at Brigham and Women's Hospital and molecular immunology at Dana Farber Cancer Institute, all in Boston. His work focuses on the mechanisms that control homeostasis and inflammation at mucosal surfaces.

Sebastian Zeissig, MD, received his medical degree from the Charité Berlin, Germany. After a postdoctoral fellowship at the same institution, Dr. Zeissig joined the laboratory of Richard $\mathrm{S}$. Blumberg as postdoctoral fellow to investigate the role of CD1d-restricted NKT cells in infectious hepatitis and immunodeficiency. Since 2010, Dr. Zeissig is leading the Laboratory of Mucosal Immunology at the Department of Internal Medicine, Kiel University (Kiel, Germany), where he continues to investigate the role of lipid antigens in intestinal and hepatic immunity. 

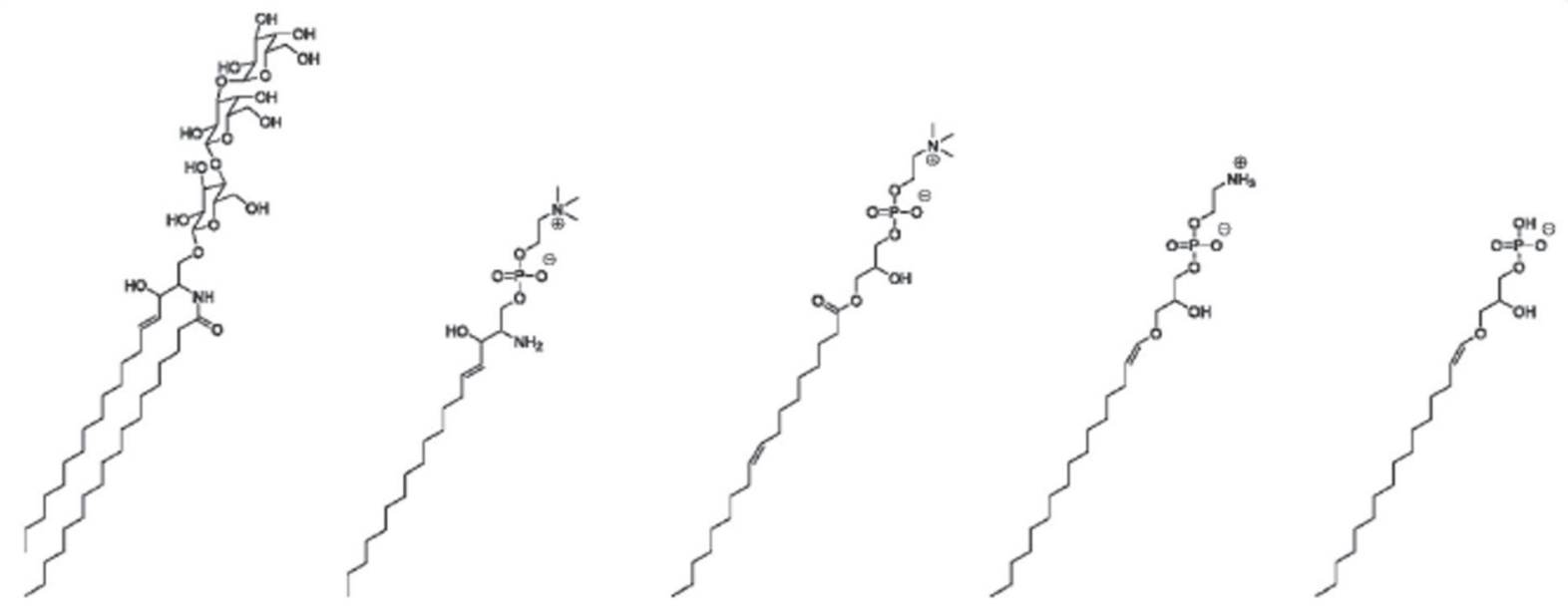

iGb3

LSM

LPC

pLPE

eLPA

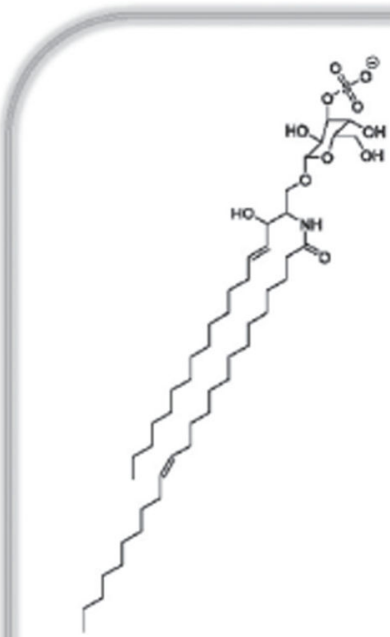

Sulfatide

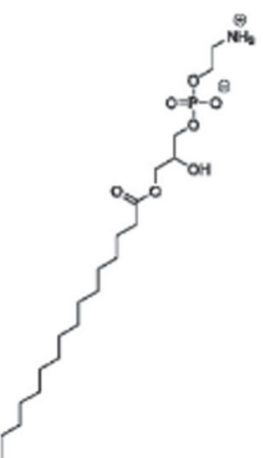

LPE

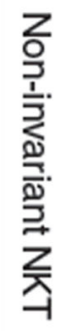

Figure 1.

Self-antigens involved in the activation of invariant and non-invariant NKT cells. 

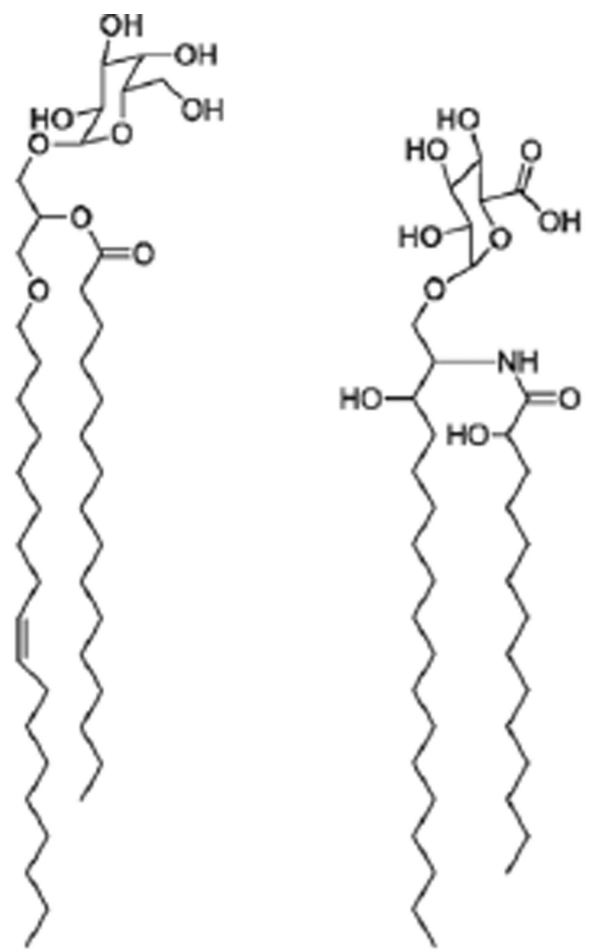

GSL-1

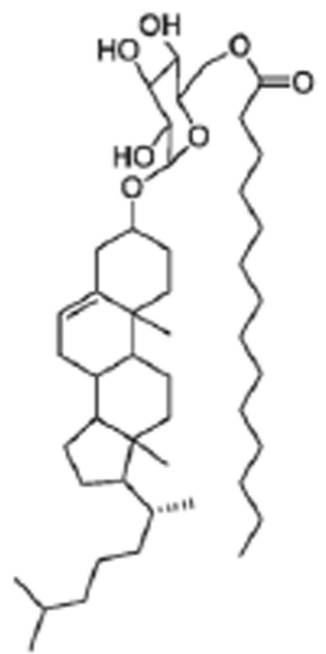

PI-57

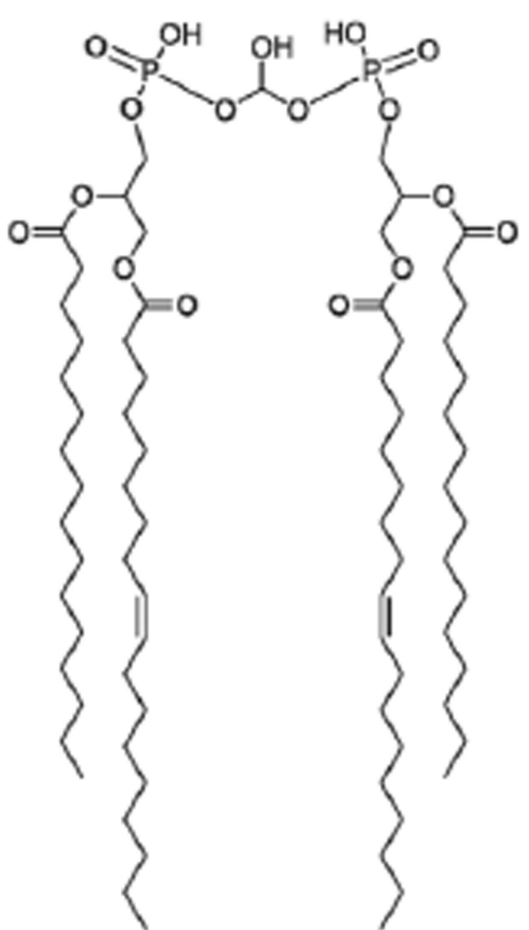

Cg-DPG

\section{Invariant NKT}

Figure 2.

Selected microbial lipid antigens that activate invariant and non-invariant NKT cells. 


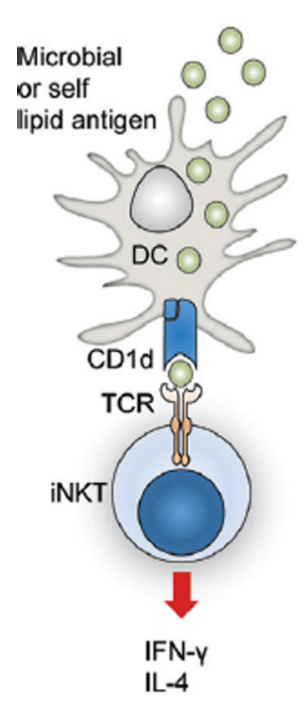

Antigen only

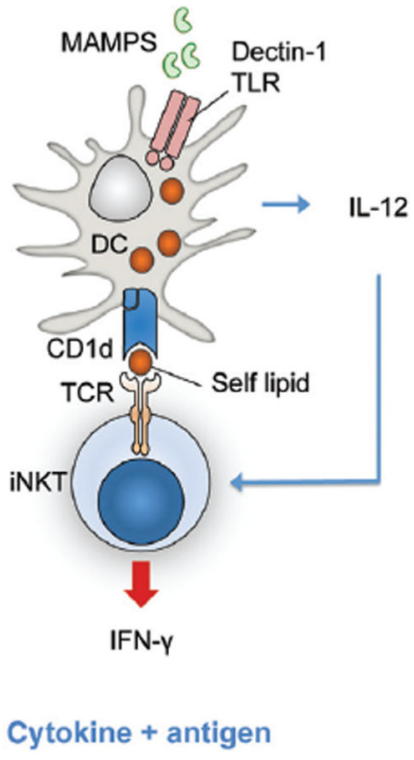

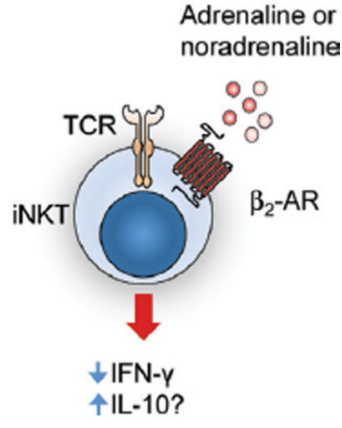

Hormone only

Figure 3.

Direct and indirect mechanisms of iNKT cell activation or modulation. $\beta_{2}$-AR, $\beta_{2}$-adrenergic receptor; DC, dendritic cell. 